\title{
LEVEL II SCOUR ANALYSIS FOR BRIDGE 29 (ROYATH00920029) on TOWN HIGHWAY 92, crossing the FIRST BRANCH WHITE RIVER, ROYALTON, VERMONT
}

Open-File Report 97-819

Prepared in cooperation with

VERMONT AGENCY OF TRANSPORTATION

and

FEDERAL HIGHWAY ADMINISTRATION

U.S. Department of the Interior

U.S. Geological Survey

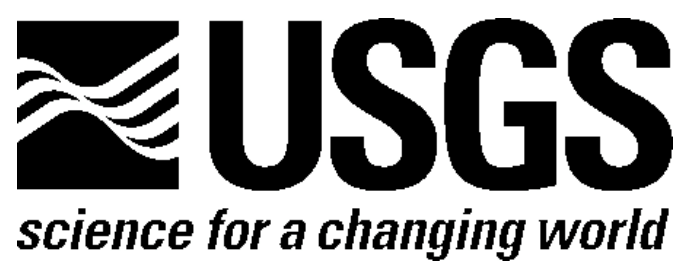




\section{LEVEL II SCOUR ANALYSIS FOR BRIDGE 29 (ROYATH00920029) on TOWN HIGHWAY 92, crossing the FIRST BRANCH WHITE RIVER, ROYALTON, VERMONT \\ By EMILY C. WILD and ROBERT E. HAMMOND}

U.S. Geological Survey Open-File Report 97-819

Prepared in cooperation with

VERMONT AGENCY OF TRANSPORTATION

and

FEDERAL HIGHWAY ADMINISTRATION 


\title{
U.S. DEPARTMENT OF THE INTERIOR BRUCE BABBITT, Secretary
}

\author{
U.S. GEOLOGICAL SURVEY \\ Mark Schaefer, Acting Director
}

For additional information write to:

District Chief

U.S. Geological Survey 361 Commerce Way

Pembroke, NH 03275-3718
Copies of this report may be purchased from:

U.S. Geological Survey

Branch of Information Services

Open-File Reports Unit

Box 25286

Denver, CO 80225-0286 


\section{CONTENTS}

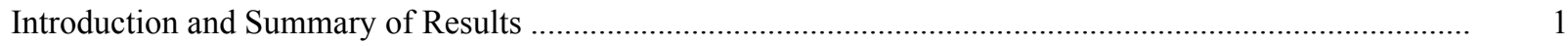

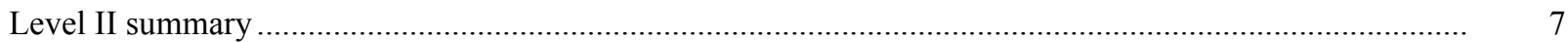

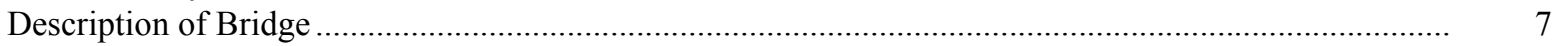

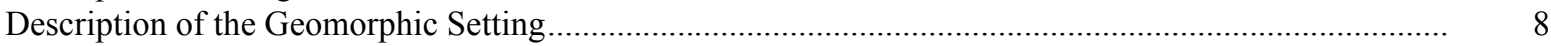

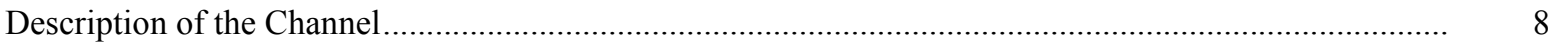

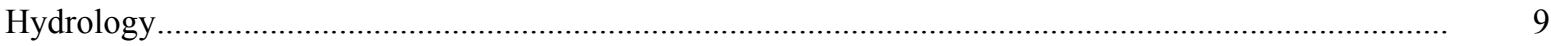

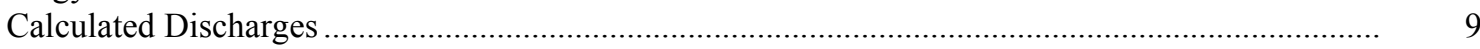

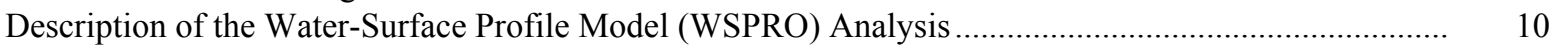

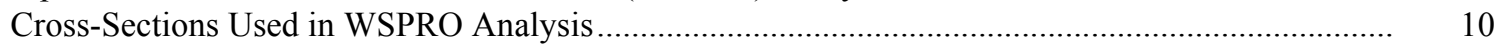

Data and Assumptions Used in WSPRO Model ...................................................................... 11

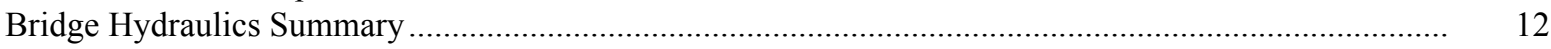

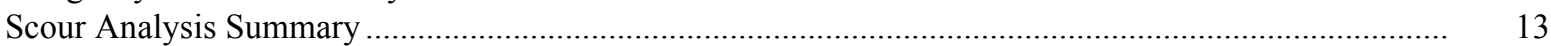

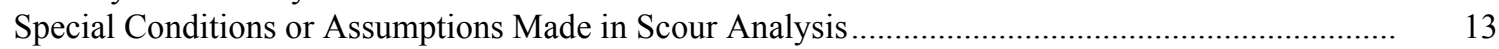

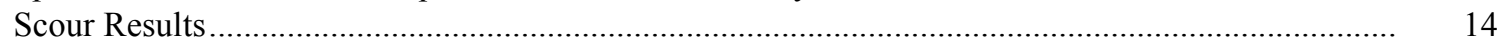

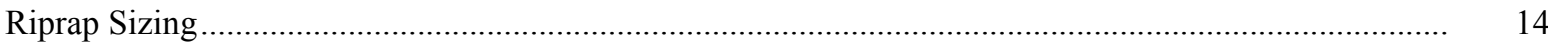

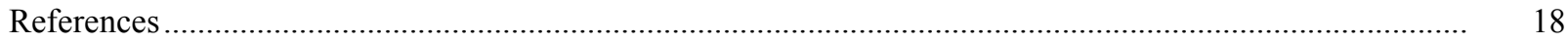

Appendixes:

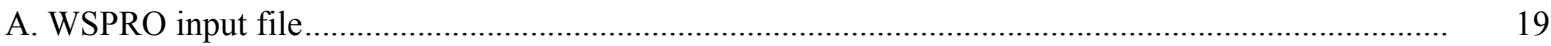

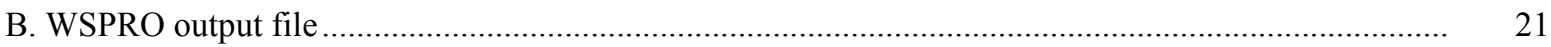

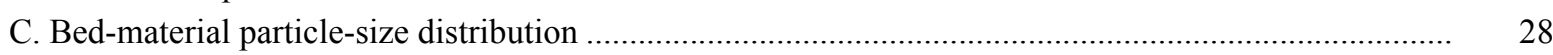

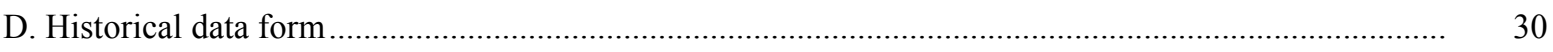

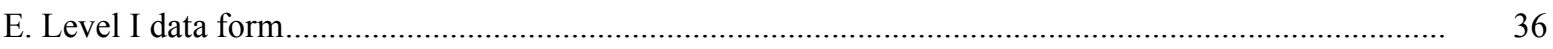

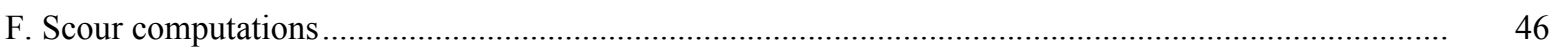

\section{FIGURES}

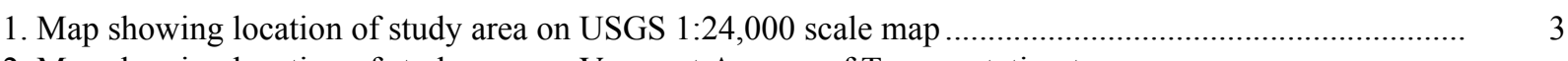

2. Map showing location of study area on Vermont Agency of Transportation town
highway map

3. Structure ROYATH00920029 viewed from upstream (July 23, 1996) …................................................

4. Downstream channel viewed from structure ROYATH00920029 (July 23, 1996). ............................... 5

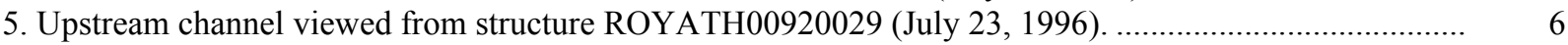

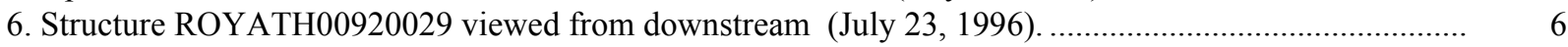

7. Water-surface profiles for the 100- and 500-year discharges at structure
ROYATH00920029 on Town Highway 92, crossing the First Branch White River,

Royalton, Vermont.

8. Scour elevations for the 100- and 500-year discharges at structure

ROYATH00920029 on Town Highway 92, crossing the First Branch White River,

Royalton, Vermont.

\section{TABLES}

1. Remaining footing/pile depth at abutments for the 100-year discharge at structure

ROYATH00920029 on Town Highway 92, crossing the First Branch White River,

Royalton, Vermont.

2. Remaining footing/pile depth at abutments for the 500-year discharge at structure

ROYATH00920029 on Town Highway 92, crossing the First Branch White River,

Royalton, Vermont. 


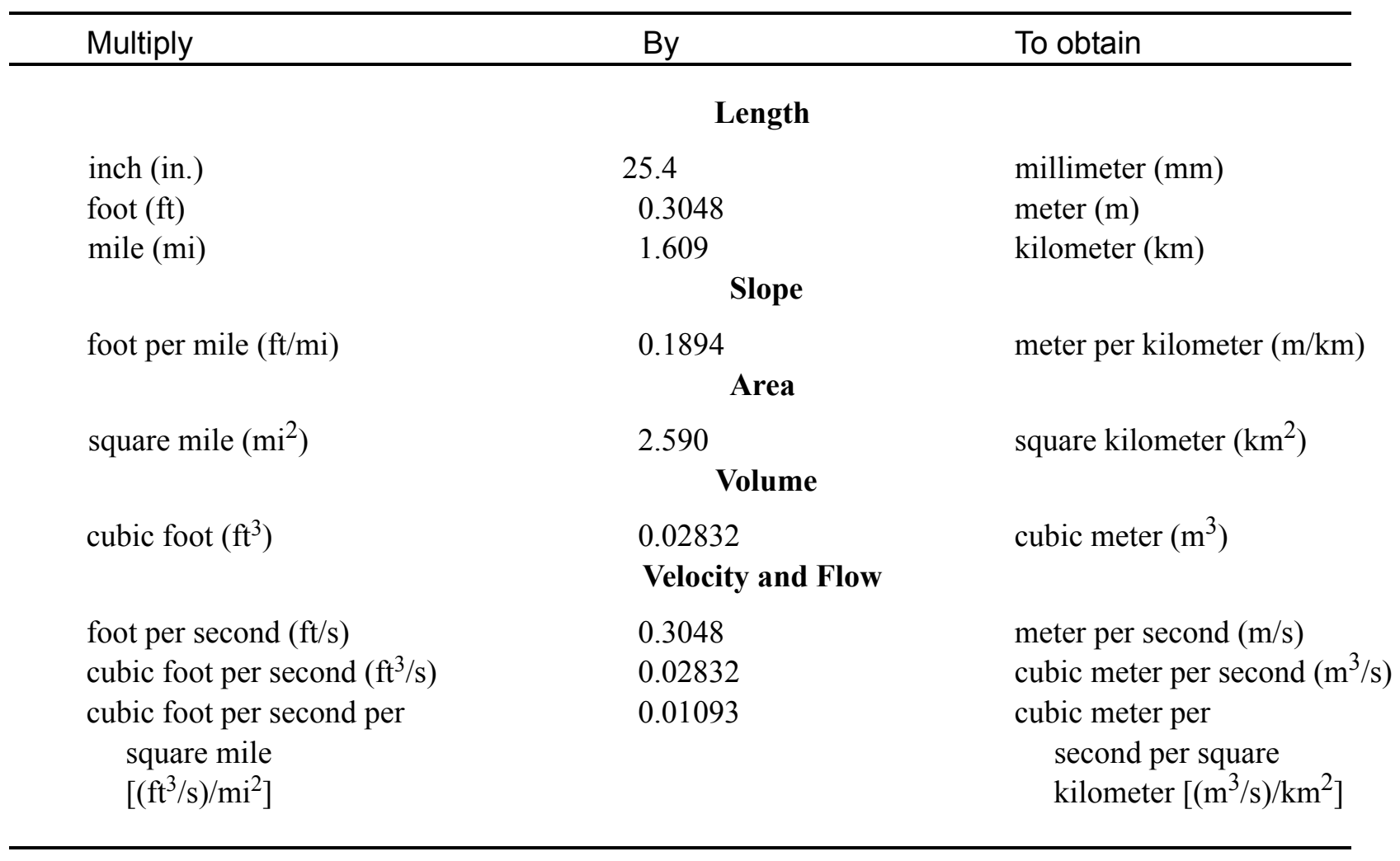

\section{OTHER ABBREVIATIONS}

$\begin{array}{lrlr}\mathrm{BF} & \text { bank full } & \text { LWW } & \text { left wingwall } \\ \mathrm{cfs} & \text { cubic feet per second } & \text { MC } & \text { main channel } \\ \mathrm{D}_{50} & \text { median diameter of bed material } & \text { RAB } & \text { right abutment } \\ \mathrm{DS} & \text { downstream } & \text { RABUT } & \text { face of right abutment } \\ \mathrm{elev} & \text { elevation } & \text { RB } & \text { right bank } \\ \mathrm{f} / \mathrm{p} & \text { flood plain } & \text { ROB } & \text { right overbank } \\ \mathrm{ft}^{2} & \text { square feet } & \text { RWW } & \text { right wingwall } \\ \mathrm{ft} / \mathrm{ft} & \text { feet per foot } & \text { TH } & \text { town highway } \\ \mathrm{JCT} & \text { junction } & \text { UB } & \text { under bridge } \\ \mathrm{LAB} & \text { left abutment } & \text { US } & \text { upstream } \\ \mathrm{LABUT} & \text { face of left abutment } & \text { USGS } & \text { United States Geological Survey } \\ \mathrm{LB} & \text { left bank } & \text { VTAOT Vermont Agency of Transportation } \\ \mathrm{LOB} & \text { left overbank } & \text { WSPRO } & \text { water-surface profile model }\end{array}$

In this report, the words "right" and "left" refer to directions that would be reported by an observer facing downstream. Sea level: In this report, "sea level" refers to the National Geodetic Vertical Datum of 1929-- a geodetic datum derived from a general adjustment of the first-order level nets of the United States and Canada, formerly called Sea Level Datum of 1929.

In the appendices, the above abbreviations may be combined. For example, USLB would represent upstream left bank. 


\title{
LEVEL II SCOUR ANALYSIS FOR BRIDGE 29 (ROYATH00920029) ON TOWN HIGHWAY 92, CROSSING THE FIRST BRANCH WHITE RIVER, ROYALTON, VERMONT
}

\author{
By Emily C. Wild and Robert E. Hammond
}

\section{INTRODUCTION AND SUMMARY OF RESULTS}

This report provides the results of a detailed Level II analysis of scour potential at structure ROYATH00920029 on Town Highway 92 crossing the First Branch White River, Royalton, Vermont (figures 1-8). A Level II study is a basic engineering analysis of the site, including a quantitative analysis of stream stability and scour (U.S. Department of Transportation, 1993). Results of a Level I scour investigation also are included in Appendix E of this report. A Level I investigation provides a qualitative geomorphic characterization of the study site. Information on the bridge, gleaned from Vermont Agency of Transportation (VTAOT) files, was compiled prior to conducting Level I and Level II analyses and is found in Appendix D.

The site is in the New England Upland section of the New England physiographic province in central Vermont. The $101-\mathrm{mi}^{2}$ drainage area is in a predominantly rural and forested basin. In the vicinity of the study site, the surface cover is pasture upstream and downstream of the bridge.

In the study area, the First Branch White River has an incised, sinuous channel with a slope of approximately $0.001 \mathrm{ft} / \mathrm{ft}$, an average channel top width of $81 \mathrm{ft}$ and an average bank height of $9 \mathrm{ft}$. The channel bed material ranges from sand to bedrock with a median grain size $\left(\mathrm{D}_{50}\right)$ of $1.18 \mathrm{~mm}(0.00347 \mathrm{ft})$. The geomorphic assessment at the time of the Level I site visit on July 23, 1996 and Level II site visit on June 2, 1995, indicated that the reach was stable.

The Town Highway 92 crossing of the First Branch White River is a 59-ft-long, one-lane bridge consisting of a 57-foot steel-stringer span (Vermont Agency of Transportation, written communication, March 23, 1995). The opening length of the structure parallel to the bridge face is $52.2 \mathrm{ft}$. The bridge is supported by vertical, concrete abutments with wingwalls. The channel is skewed approximately 20 degrees to the opening while the opening-skew-to-roadway is zero degrees. 
A scour hole $4.0 \mathrm{ft}$ deeper than the mean thalweg depth was observed in the upstream channel during the Level I assessment. The only scour protection measure at the site was type-2 stone fill (less than 36 inches diameter) along the upstream left and right wingwalls, the left abutment and downstream left wingwall. Additional details describing conditions at the site are included in the Level II Summary and Appendices D and E.

Scour depths and recommended rock rip-rap sizes were computed using the general guidelines described in Hydraulic Engineering Circular 18 (Richardson and others, 1995) for the 100- and 500-year discharges. In addition, the incipient roadway-overtopping discharge was determined and analyzed as another potential worst-case scour scenario. Total scour at a highway crossing is comprised of three components: 1) long-term streambed degradation; 2) contraction scour (due to accelerated flow caused by a reduction in flow area at a bridge) and; 3) local scour (caused by accelerated flow around piers and abutments). Total scour is the sum of the three components. Equations are available to compute depths for contraction and local scour and a summary of the results of these computations follows.

Contraction scour for all modelled flows ranged from 0.0 to $4.1 \mathrm{ft}$. The worst-case contraction scour occurred at the incipient roadway-overtopping discharge, which was less than the 100-year discharge. Left abutment scour ranged from 12.9 to $15.4 \mathrm{ft}$, where the worst-case abutment scour occurred at the 500-year discharge. Right abutment scour ranged from 14.5 to $15.0 \mathrm{ft}$, where the worst-case abutment scour occurred at the 100 -year discharge. Additional information on scour depths and depths to armoring are included in the section titled "Scour Results". Scoured-streambed elevations, based on the calculated scour depths, are presented in tables 1 and 2. A cross-section of the scour computed at the bridge is presented in figure 8 . Scour depths were calculated assuming an infinite depth of erosive material and a homogeneous particle-size distribution.

It is generally accepted that the Froehlich equation (abutment scour) gives "excessively conservative estimates of scour depths" (Richardson and others, 1995, p. 47). Usually, computed scour depths are evaluated in combination with other information including (but not limited to) historical performance during flood events, the geomorphic stability assessment, existing scour protection measures, and the results of the hydraulic analyses. Therefore, scour depths adopted by VTAOT may differ from the computed values documented herein. 


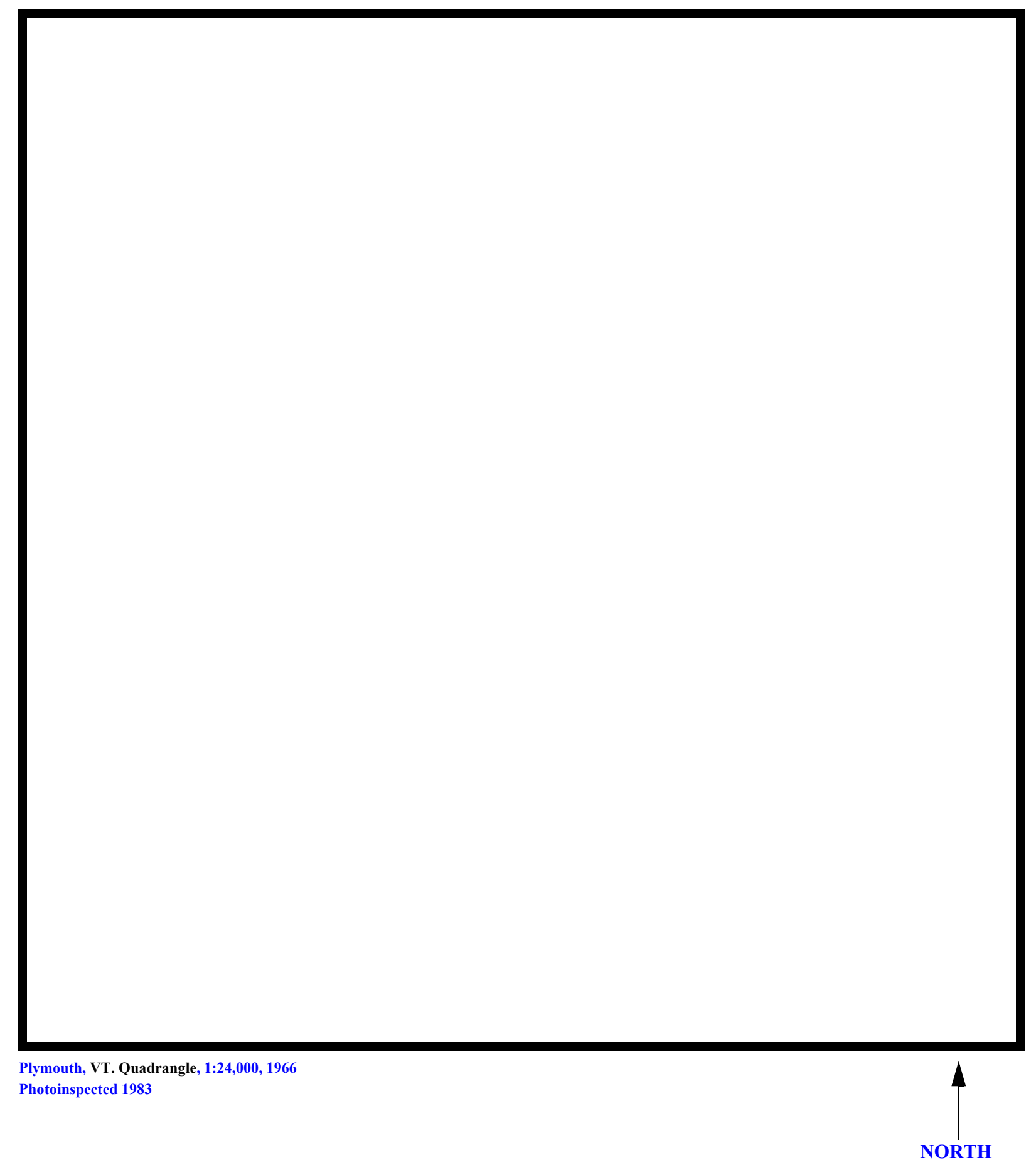

Figure 1. Location of study area on USGS 1:24,000 scale map. 
Figure 2. Location of study area on Vermont Agency of Transportation town highway map. 

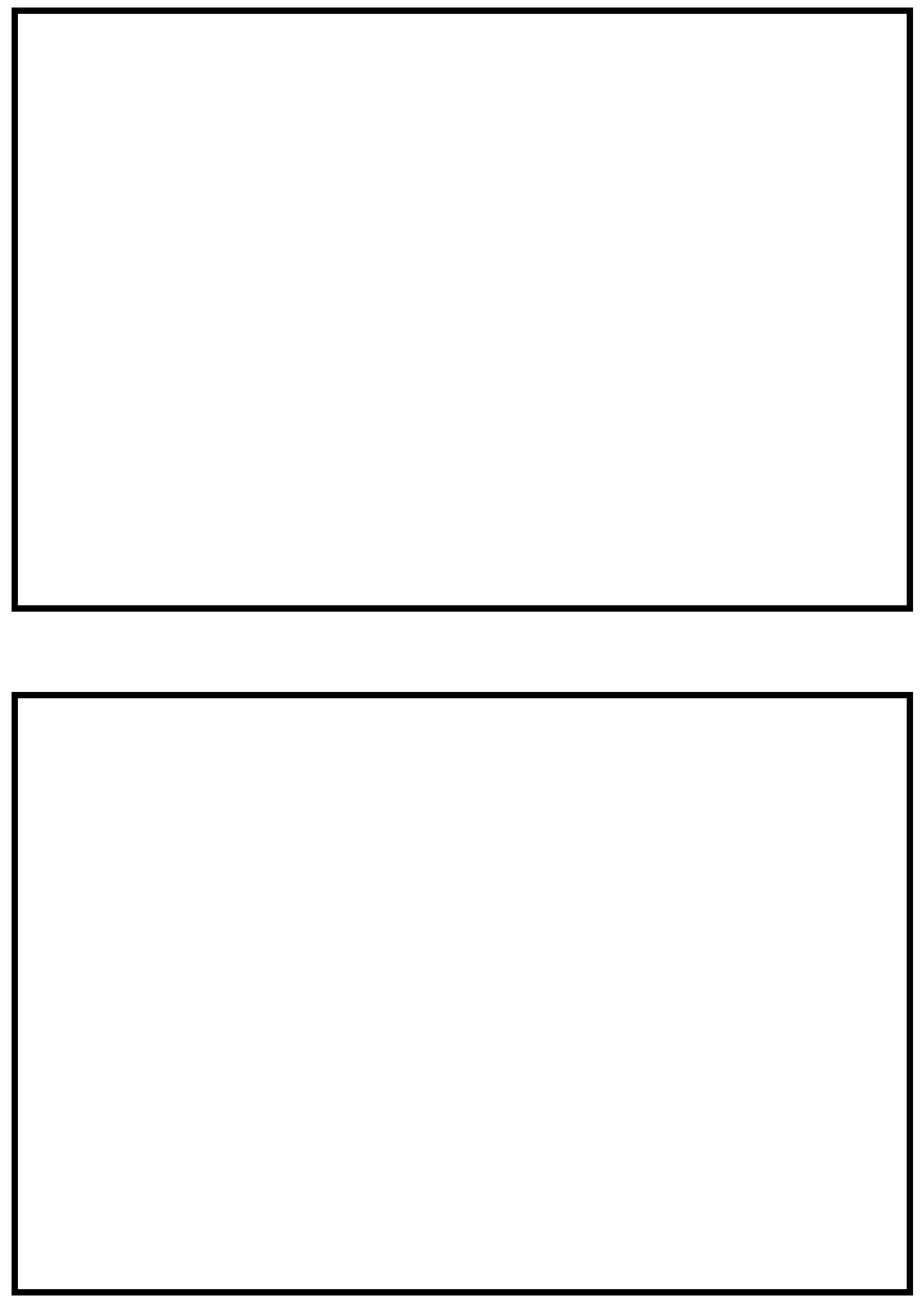

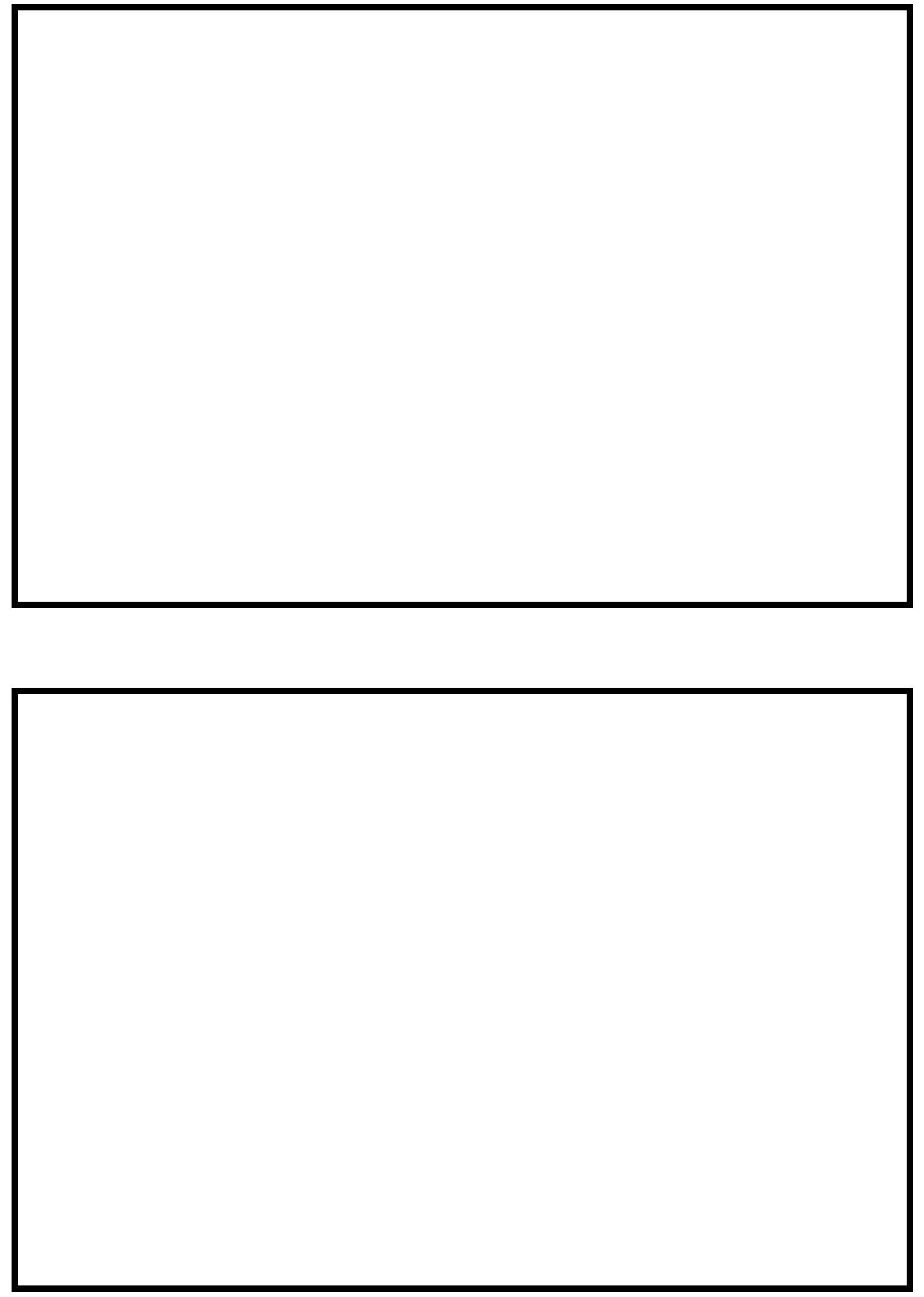


\section{LEVEL II SUMMARY}

\begin{tabular}{llllll} 
Structure Number & ROYATH00920029 & \multirow{2}{*}{ Stream } & \multicolumn{3}{c}{ First Branch White River } \\
& Road & TH92 & District & 4
\end{tabular}

\section{Description of Bridge}

Bridge length $\stackrel{59}{\quad} \boldsymbol{f t}$ Bridge width $\frac{12.3}{f t}$ Max span length $\stackrel{57}{ } \boldsymbol{f t}$ Alignment of bridge to road (on curve or straight)

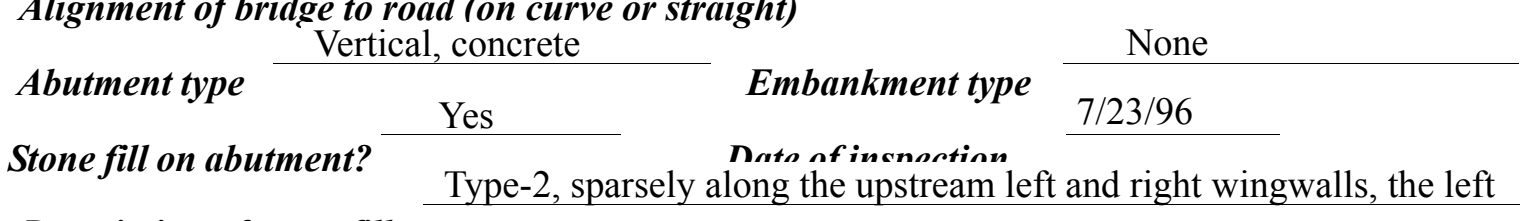
Dnconintinu af otann fill Type-2, sparsely along the upstream left and right wingwalls, the left abutment and the downstream left wingwall..

Abutments and wingwalls are concrete.

$\ldots \ldots \ldots$

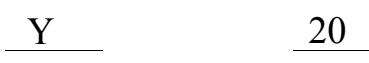

Is bridge skewed to flood flow according to $\mathrm{N} \quad$ r survey? Angle

There is a mild channel bend in the upstream reach. The scour hole has developed in the upstream reach where the stream becomes constricted.

Debris accumulation on bridge at time of Level I or Level II site visit:

\begin{tabular}{|c|c|c|c|}
\hline & $\begin{array}{c}\text { Date of insnortion } \\
7 / 23 / 96 \\
\end{array}$ & $\begin{array}{l}\text { Percent of almmual } \\
\text { blocked inortzontatly }\end{array}$ & $\begin{array}{l}\text { Percent of } 0 \\
\text { blocked verticatty }\end{array}$ \\
\hline Level I & $6 / 02 / 95$ & 0 & 0 \\
\hline el II & Low. & & \\
\hline
\end{tabular}

\section{Potential for debris}

None, 7/23/96.

Doscriho anv fonturos noar ar at tho hridoo that mav affort flow, (includo ahsorvation dato) 


\section{Description of the Geomorphic Setting}

General topography The channel is located within a narrow, irregular flood plain with a steep valley wall on the left side.

Geomorphic conditions at bridge site: downstream (DS), upstream (US)

Date of inspection $\quad 7 / 23 / 96$

DS left: $\quad$ Narrow flood plain, with a verical bedrock wall.

DS right: $\quad$ Narrow flood plain.

US left: $\quad$ Moderately sloped overbank.

US right: Narrow flood plain.

\section{Description of the Channel}

\begin{tabular}{|c|c|c|c|}
\hline \multirow[b]{2}{*}{ Average top width } & 81 & \multirow[b]{2}{*}{ Average depth } & \multirow[b]{2}{*}{ Sand / Gravel } \\
\hline & Silt / Sand & & \\
\hline Predominant bed m & & Bank material & Sinuous but stable \\
\hline
\end{tabular}

with semi-allúvial channel boundaries and a narrow flood plain.

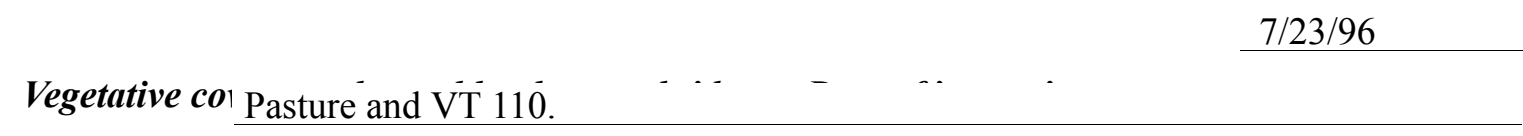

DS left: $\quad$ Pasture.

DS right: $\quad$ Pasture with VT 110 along immediate bank.

US left: $\quad$ Pasture.

US right: $\quad \underline{\mathrm{Y}}$

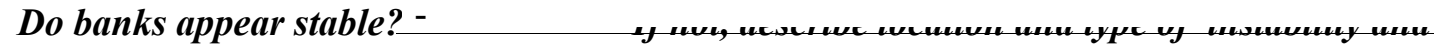

date of observatton.

96 noted no obstructions in the channel.

Describe any obstructions in channel and date of observation. 


\section{Hydrology}

Drainage area $\frac{101}{m i^{2}}$

Percentage of drainage area in physiographic provinces: (approximate)

Physiographic province/section New England/New England Upland
Percent of drainage area 100

Is drainage area considered rural or urban? Rural Describe any significant urbanization:

Is there a USGS gage on the stream of interest?

No

$-$

\section{USGS gage description}

USGS gage number

Gage drainage area $\mathrm{mi}^{2}$

$m i^{2}$ No

Is there a lake/p -

\section{Calculated Discharges $\quad \underline{22,000}$

Q100 $\quad \mathrm{ft} / \mathrm{s} \quad \mathrm{Q500} \quad \mathrm{ft} / \mathrm{s}$

The 100- and 500-year discharges are from the

Flood Insurance Study of the Town of Royalton (Federal Emergency Management Agency, 1989). The values computed are within a range defined by several empirical flood frequency curves (Benson, 1962; Johnson and Tasker, 1974; FHWA, 1983; Potter, 1957a\&b; Talbot, 1887). 


\section{Description of the Water-Surface Profile Model (WSPRO) Analysis}

Datum for WSPRO analysis (USGS survey, sea level, VTAOT plans) ～USGS survey

Datum tie between USGS survey and VTAOT plans $\quad$ To obtain the Federal Emergency

Management Agency's datum (sea level), add $3.1 \mathrm{ft}$ to USGS survey.

Description of reference marks used to determine USGS datum. $\quad$ RM1 is a chiseled X on top of the downstream end of the left abutment (elev. $498.69 \mathrm{ft}$, arbitrary survey datum). RM2 is

a chiseled X on top of the upstream end of the right abutment (elev. $498.40 \mathrm{ft}$, arbitrary survey

datum). RM3 is a "VT" concrete post behind the downstream left wingwall (elev. $498.41 \mathrm{ft}$, arbitrary survey datum).

\section{Cross-Sections Used in WSPRO Analysis}

\begin{tabular}{cccl}
\hline${ }^{1}$ Cross-section & $\begin{array}{c}\text { Section } \\
\text { Reference } \\
\text { Distance } \\
\text { (SRD) in feet }\end{array}$ & $\begin{array}{c}{ }^{2} \text { Cross-section } \\
\text { development }\end{array}$ & \multicolumn{1}{c}{ Comments } \\
\hline EXIT2 & -529 & 1 & Exit section \\
\hline EXITX & -57 & 1 & Exit section \\
FULLV & 0 & 2 & $\begin{array}{l}\text { Downstream Full-valley } \\
\text { section (Templated from } \\
\text { EXITX) }\end{array}$ \\
BRIDG & 0 & 1 & $\begin{array}{l}\text { Bridge section } \\
\text { RDWAY }\end{array}$ \\
APTEM & 8 & 1 & $\begin{array}{l}\text { Road Grade section } \\
\text { Approach section as sur- } \\
\end{array}$ \\
APPR1 & 56 & 1 & $\begin{array}{l}\text { veyed (Used as a tem- } \\
\text { plate) }\end{array}$ \\
& 69 & 2 & $\begin{array}{l}\text { Modelled Approach sec- } \\
\text { tion (Templated from } \\
\text { APTEM) }\end{array}$ \\
\hline
\end{tabular}

${ }^{1}$ For location of cross-sections see plan-view sketch included with Level I field form, Appendix E. For more detail on how cross-sections were developed see WSPRO input file. 


\section{Data and Assumptions Used in WSPRO Model}

Hydraulic analyses of the reach were done by use of the Federal Highway Administration's WSPRO step-backwater computer program (Shearman and others, 1986, and Shearman, 1990). The analyses reported herein reflect conditions existing at the site at the time of the study. Furthermore, in the development of the model it was necessary to assume no accumulation of debris or ice at the site. Results of the hydraulic model are presented in the Bridge Hydraulic Summary, Appendix B, and figure 7.

Channel roughness factors (Manning's " $n$ ") used in the hydraulic model were estimated using field inspections at each cross section following the general guidelines described by Arcement and Schneider (1989). Final adjustments to the values were made during the modelling of the reach. Channel " $\mathrm{n}$ " values for the reach ranged from 0.033 to 0.040 , and overbank " $n$ " values ranged from 0.030 to 0.037 .

Normal depth at the downstream-most exit section (EXIT2) was assumed as the starting water surface. This depth was computed by use of the slope-conveyance method outlined in the

user's manual for WSPRO (Shearman, 1990). The slope used was $0.0013 \mathrm{ft} / \mathrm{ft}$ which was estimated from the topographic map (U.S. Geological Survey, 1981).

The surveyed approach section (APTEM) was moved along the approach channel slope $(0.0011 \mathrm{ft} / \mathrm{ft})$ to establish the modelled approach section (APPR1), one bridge length upstream of the upstream face as recommended by Shearman and others (1986). This location also provides a consistent method for determining scour variables. 


\section{Bridge Hydraulics Summary}

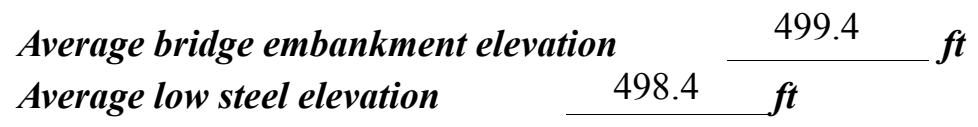

100-year discharge $\quad 15,000 \quad \mathrm{ft}^{3} / \mathrm{s}$

Water-surface elevation in bridge opening $\quad 498.7 \quad f t$

Road overtopping? ___ Y Discharge over road _ـ 8,360 $\boldsymbol{f t}^{3} / \mathrm{s}$

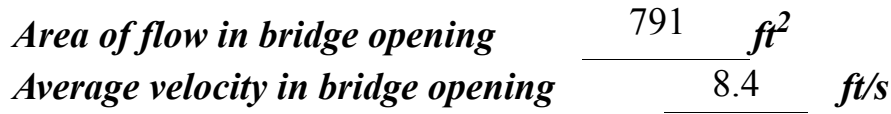

$\begin{array}{lll}\text { Maximum WSPRO tube velocity at bridge } & 10.2 \mathrm{ft} / \mathrm{s}\end{array}$

Water-surface elevation at Approach section with bridge 503.5

Water-surface elevation at Approach section without bridge $\quad 502.8$

Amount of backwater caused by bridge $\quad 0.7 \quad$ it

500-year discharge $\quad 22,000 \quad f^{3} / s$

Water-surface elevation in bridge opening $\quad 498.7 \mathrm{ft}$

Road overtopping? ___ Y Discharge over road _ $16,600 \mathrm{ft}^{3} / \mathrm{s}$

$\begin{array}{llll}\text { Area of flow in bridge opening } & 791 \quad \boldsymbol{f t}^{2} & \\ \text { Average velocity in bridge opening } & & 7.0 \quad \mathrm{ft} / \mathrm{s}\end{array}$

Maximum WSPRO tube velocity at bridge 8.5 's

Water-surface elevation at Approach section with bridge 505.8

Water-surface elevation at Approach section without bridge $\quad 505.9$

Amount of backwater caused by bridge N/A,t

Incipient overtopping discharge $\quad 6,980 \mathrm{ft}^{3} / \mathrm{s}$

Water-surface elevation in bridge opening $497.0 \quad t$

\begin{tabular}{llll} 
Area of flow in bridge opening & $715 \quad \boldsymbol{f t}^{\mathbf{2}}$ \\
\cline { 2 - 3 } Average velocity in bridge opening & $9.8 \quad \mathrm{ft} / \mathrm{s}$
\end{tabular}

Maximum WSPRO tube velocity at bridge $\quad 12.6 \mathrm{ft} / \mathrm{s}$

Water-surface elevation at Approach section with bridge

Water-surface elevation at Approach section without bridge

Amount of backwater caused by bridge $\quad 0.3$.t

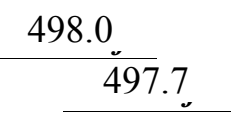




\section{Scour Analysis Summary}

\section{Special Conditions or Assumptions Made in Scour Analysis}

Scour depths were computed using the general guidelines described in Hydraulic Engineering Circular 18 (Richardson and others, 1995). Scour depths were calculated assuming an infinite depth of erosive material and a homogeneous particle-size distribution. The results of the 100-year and 500-year scour analyses are presented in tables 1 and 2 and a graph of the scour depths is presented in figure 8 .

At this site, the 100-year and 500-year discharges resulted in submerged orifice flow, for which, contraction scour is frequently estimated by use of the Chang pressure-flow scour equation. However, the Chang equation for was derived solely with data for clear-water conditions. Under live-bed conditions, the Chang equation "may yield overly conservative results" (Richardson and others, 1995, p. 147-148). Therefore, contraction scour for the 100year, 500-year, and incipient roadway-overtopping discharges was computed by use of the Laursen live-bed contraction scour equation (Richardson and others, 1995, p. 30, equation 17). For comparison, contraction scour for the discharges resulting in orifice flow was also computed by use of the Umbrell pressure-flow equation (Richardson and others, 1995, p. 144) and presented in Appendix F.

Abutment scour for the left abutment was computed by use of the Froehlich equation (Richardson and others, 1995, p. 48, equation 28). Variables for the Froehlich equation include the Froude number of the flow approaching the embankments, the length of the embankment blocking flow, and the depth of flow approaching the embankment less any roadway overtopping.

Scour at the right abutment was computed by use of the HIRE equation (Richardson and others, 1995, p. 49, equation 29) because the HIRE equation is recommended when the length to depth ratio of the embankment blocking flow exceeds 25 . The variables used by the HIRE abutment-scour equation are defined the same as those defined for the Froehlich abutment-scour equation. 


\section{Scour Results}

100-yr discharge 500-yrdischarge

Incipient

Contraction scour:

(Scour depths in feet)

Main channel

Live-bed scour

1.0

Clear-water scour

Depth to armoring

Left overbank

Right overbank

Local scour:

Abutment scour

Left abutment

Right abutment

Pier scour

Pier 1

Pier 2

Pier 3

N/A N/

$-$

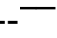

- overtopping discharge
12.9

15.0
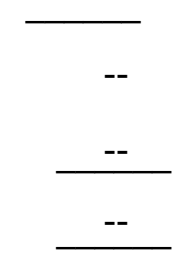

\section{Riprap Sizing}

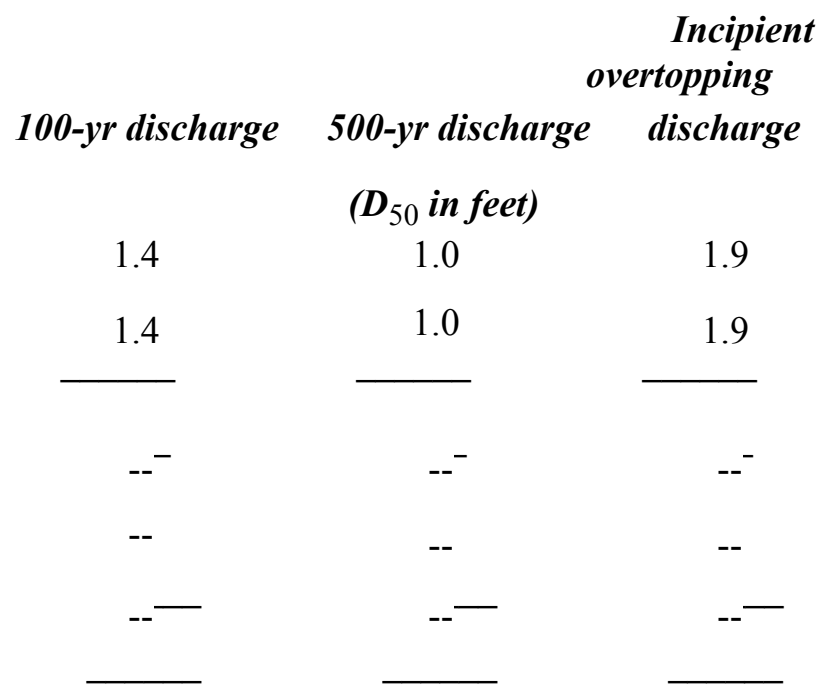




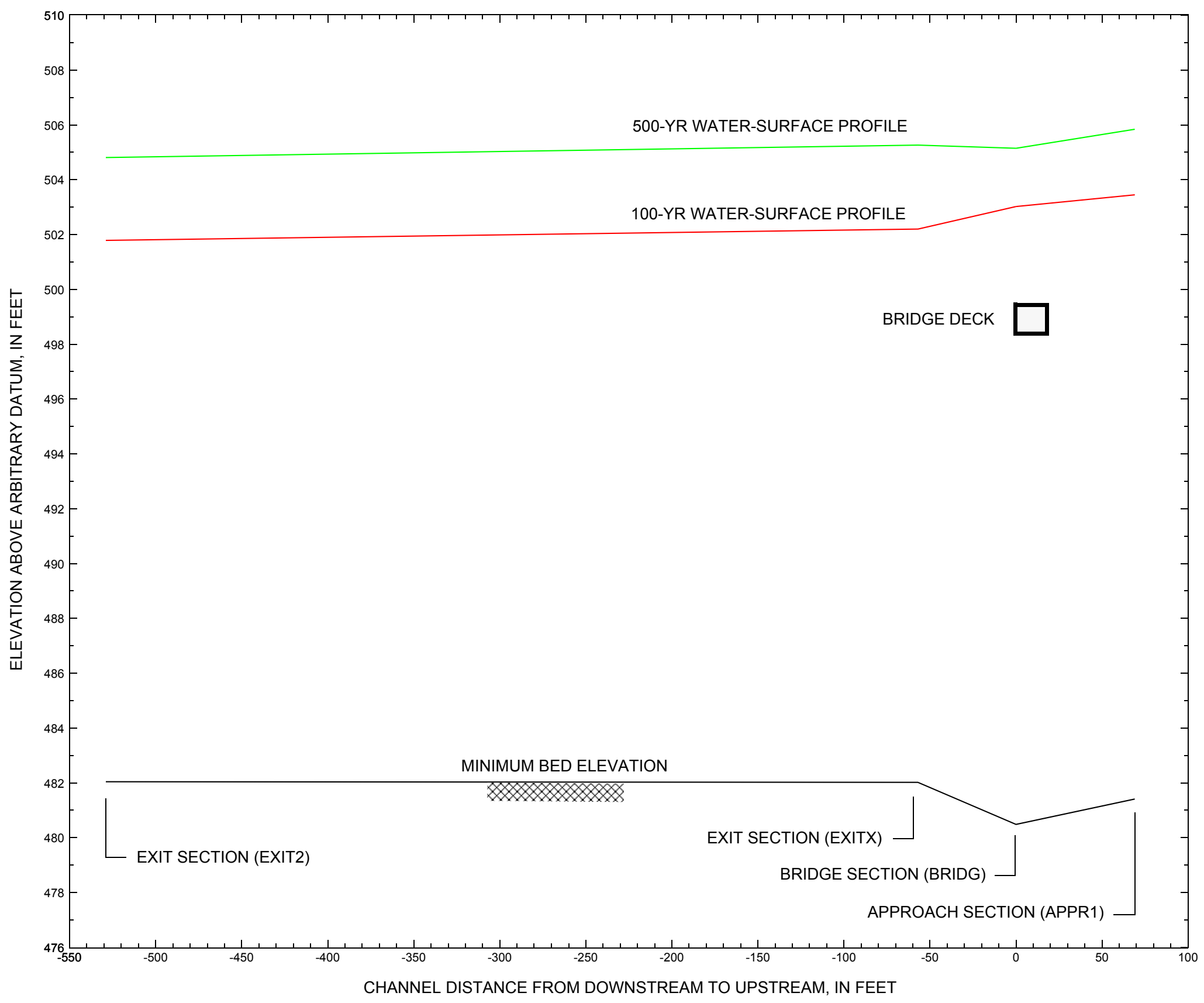

Figure 7. Water-surface profiles for the 100- and 500-yr discharges at structure ROYATH00920029 on Town Highway 92 , crossing the First Branch White River, Royalton, Vermont. 


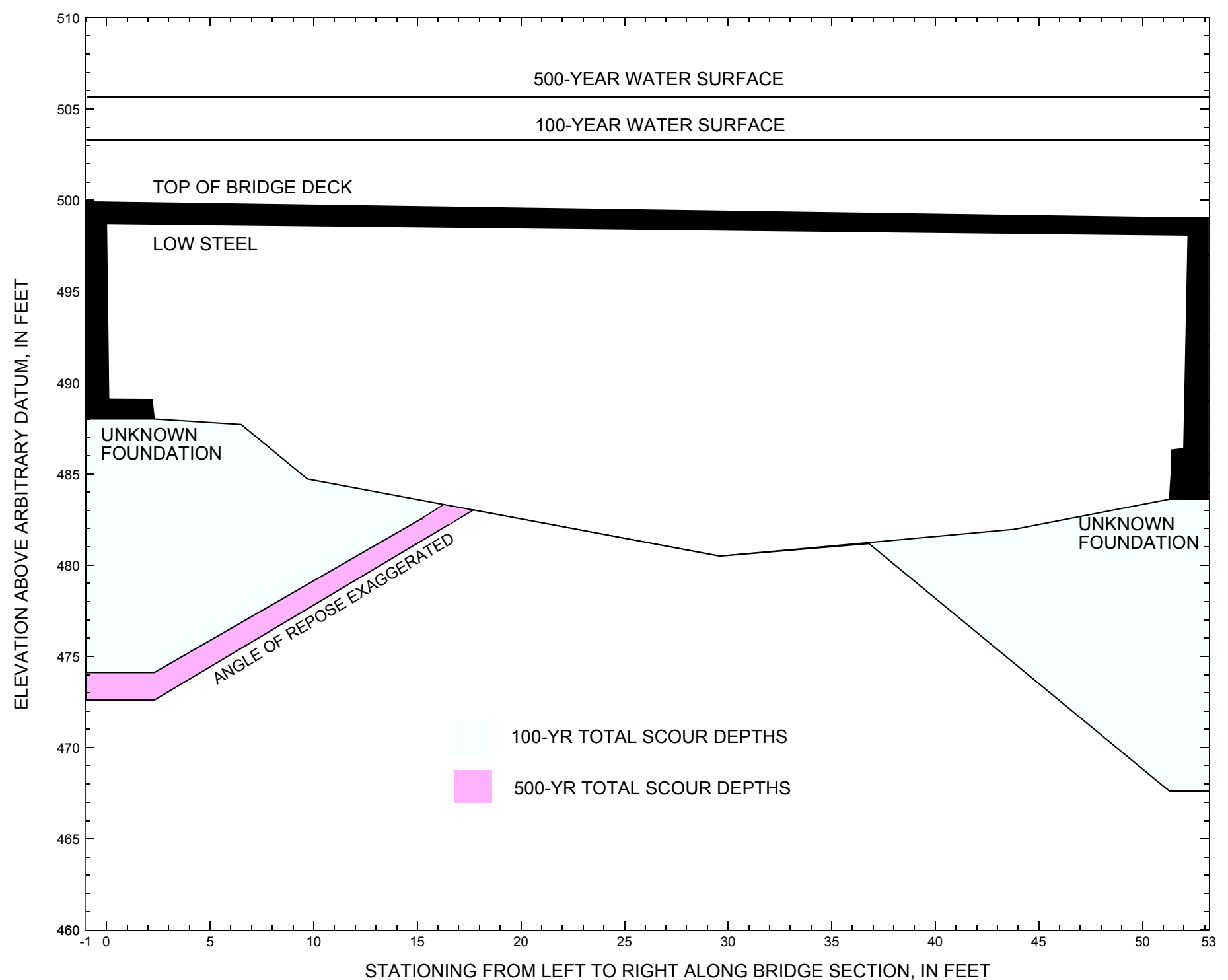

Figure 8. Scour elevations for the 100-yr and 500-yr discharges at structure ROYATH00920029 on Town Highway 92, crossing the First Branch White River, Royalton, Vermont. 
Table 1. Remaining footing/pile depth at abutments for the 100-year discharge at structure ROYATH00920029 on Town Highway 92, crossing the First Branch White River, Royalton, Vermont.

[VTAOT, Vermont Agency of Transportation; --,no data]

\begin{tabular}{|c|c|c|c|c|c|c|c|c|c|c|c|}
\hline Description & Station $^{1}$ & $\begin{array}{l}\text { FEMA } \\
\text { minimum } \\
\text { low-chord } \\
\text { elevation } \\
\text { (feet) }\end{array}$ & $\begin{array}{l}\text { Surveyed } \\
\text { minimum } \\
\text { low-chord } \\
\text { elevation }{ }^{2} \\
\text { (feet) }\end{array}$ & $\begin{array}{c}\text { Bottom of } \\
\text { footing/pile } \\
\text { elevation }{ }^{2} \\
\text { (feet) }\end{array}$ & $\begin{array}{c}\text { Channel } \\
\text { elevation at } \\
\text { abutment/ } \\
\text { pier }{ }^{2} \\
\text { (feet) }\end{array}$ & $\begin{array}{l}\text { Contraction } \\
\text { scour depth } \\
\text { (feet) }\end{array}$ & $\begin{array}{l}\text { Abutment } \\
\text { scour } \\
\text { depth } \\
\text { (feet) }\end{array}$ & $\begin{array}{l}\text { Pier } \\
\text { scour } \\
\text { depth } \\
\text { (feet) }\end{array}$ & $\begin{array}{l}\text { Depth of } \\
\text { total scour } \\
\text { (feet) }\end{array}$ & $\begin{array}{c}\text { Elevation of } \\
\text { scour }^{2} \\
\text { (feet) }\end{array}$ & $\begin{array}{c}\text { Remaining } \\
\text { footing/pile } \\
\text { depth } \\
\text { (feet) }\end{array}$ \\
\hline \multicolumn{12}{|c|}{100 -yr. discharge is 15,000 cubic-feet per second } \\
\hline Left abutment & 0.0 & 502 & 498.7 & -- & 488.0 & 1.0 & 12.9 & -- & 13.9 & 474.1 & -- \\
\hline Right abutment & 52.2 & 501 & 498.1 & -- & 483.6 & 1.0 & 15.0 & -- & 16.0 & 467.6 & -- \\
\hline
\end{tabular}

1.Measured along the face of the most constricting side of the bridge.

2.Arbitrary datum for this study.

Table 2. Remaining footing/pile depth at abutments for the 500-year discharge at structure ROYATH00920029 on Town Highway 92, crossing the First Branch White River, Royalton, Vermont.

[VTAOT, Vermont Agency of Transportation; --, no data]

\begin{tabular}{|c|c|c|c|c|c|c|c|c|c|c|c|}
\hline Description & Station $^{1}$ & $\begin{array}{c}\text { FEMA } \\
\text { minimum } \\
\text { low-chord } \\
\text { elevation } \\
\text { (feet) }\end{array}$ & $\begin{array}{c}\text { Surveyed } \\
\text { minimum } \\
\text { low-chord } \\
\text { elevation } \\
\text { (feet) }\end{array}$ & $\begin{array}{c}\text { Bottom of } \\
\text { footing/pile } \\
\text { elevation }{ }^{2} \\
\text { (feet) }\end{array}$ & $\begin{array}{c}\text { Channel } \\
\text { elevation at } \\
\text { abutment/ } \\
\text { pier }^{2} \\
\text { (feet) }\end{array}$ & $\begin{array}{l}\text { Contraction } \\
\text { scour depth } \\
\text { (feet) }\end{array}$ & $\begin{array}{c}\text { Abutment } \\
\text { scour } \\
\text { depth } \\
\text { (feet) }\end{array}$ & $\begin{array}{l}\text { Pier } \\
\text { scour } \\
\text { depth } \\
\text { (feet) }\end{array}$ & $\begin{array}{l}\text { Depth of } \\
\text { total scour } \\
\text { (feet) }\end{array}$ & $\begin{array}{c}\text { Elevation of } \\
\text { scour }^{2} \\
\text { (feet) }\end{array}$ & $\begin{array}{c}\text { Remaining } \\
\text { footing/pile } \\
\text { depth } \\
\text { (feet) }\end{array}$ \\
\hline \multicolumn{12}{|c|}{500 -yr. discharge is 22,000 cubic-feet per second } \\
\hline Left abutment & 0.0 & 502 & 498.7 & -- & 488.0 & 0.0 & 15.4 & -- & 15.4 & 472.6 & -- \\
\hline Right abutment & 52.2 & 501 & 498.1 & -- & 483.6 & 0.0 & 14.5 & -- & 14.5 & 469.1 & -- \\
\hline
\end{tabular}

1.Measured along the face of the most constricting side of the bridge.

2.Arbitrary datum for this study. 


\section{SELECTED REFERENCES}

Arcement, G.J., Jr., and Schneider, V.R., 1989, Guide for selecting Manning's roughness coefficients for natural channels and flood plains: U.S. Geological Survey Water-Supply Paper 2339, 38 p.

Barnes, H.H., Jr., 1967, Roughness characteristics of natural channels: U.S. Geological Survey Water-Supply Paper 1849,213 p.

Benson, M. A., 1962, Factors Influencing the Occurrence of Floods in a Humid Region of Diverse Terrain: U.S. Geological Survey WaterSupply Paper 1580-B, 64 p.

Brown, S.A. and Clyde, E.S., 1989, Design of riprap revetment: Federal Highway Administration Hydraulic Engineering Circular No. 11, Publication FHWA-IP-89-016, 156 p.

Federal Highway Administration, 1983, Runoff estimates for small watersheds and development of sound design: Federal Highway Administration Report FHWA-RD-77-158.

Federal Highway Administration, 1993, Stream Stability and Scour at Highway Bridges: Participant Workbook: Federal Highway Administration Report FHWA-HI-91-011.

Federal Emergency Management Agency, 1989, Flood Insurance Study, Town of Royalton, Windsor County, Vermont: Washington, D.C., June 5, 1989.

Froehlich, D.C., 1989, Local scour at bridge abutments in Ports, M.A., ed., Hydraulic Engineering--Proceedings of the 1989 National Conference on Hydraulic Engineering: New York, American Society of Civil Engineers, p. 13-18.

Hayes, D.C.,1993, Site selection and collection of bridge-scour data in Delaware, Maryland, and Virginia: U.S. Geological Survey WaterResources Investigation Report 93-4017, 23 p.

Interagency Advisory Committee on Water Data, 1982, Guidelines for determining flood flow frequency: U.S. Geological Survey, Bulletin 17B of the Hydrology Subcommittee, 190 p.

Johnson, C.G. and Tasker, G.D.,1974, Progress report on flood magnitude and frequency of Vermont streams: U.S. Geological Survey OpenFile Report 74-130, 37 p.

Lagasse, P.F., Schall, J.D., Johnson, F., Richardson, E.V., Chang, F., 1995, Stream Stability at Highway Structures: Federal Highway Administration Hydraulic Engineering Circular No. 20, Publication FHWA-IP-90-014, 144 p.

Laursen, E.M., 1960, Scour at bridge crossings: Journal of the Hydraulics Division, American Society of Civil Engineers, v. 86, no. HY2, p. 39-53.

Potter, W. D., 1957a, Peak rates of runoff in the Adirondack, White Mountains, and Maine woods area, Bureau of Public Roads

Potter, W. D., 1957b, Peak rates of runoff in the New England Hill and Lowland area, Bureau of Public Roads

Richardson, E.V. and Davis, S.R., 1995, Evaluating scour at bridges: Federal Highway Administration Hydraulic Engineering Circular No. 18, Publication FHWA-IP-90-017, 204 p.

Richardson, E.V., Simons, D.B., and Julien, P.Y., 1990, Highways in the river environment: Federal Highway Administration Publication FHWA-HI-90-016.

Ritter, D.F., 1984, Process Geomorphology: W.C. Brown Co., Debuque, Iowa, 603 p.

Shearman, J.O., 1990, User's manual for WSPRO--a computer model for water surface profile computations: Federal Highway Administration Publication FHWA-IP-89-027, 187 p.

Shearman, J.O., Kirby, W.H., Schneider, V.R., and Flippo, H.N., 1986, Bridge waterways analysis model; research report: Federal Highway Administration Publication FHWA-RD-86-108, 112 p.

Talbot, A.N., 1887, The determination of water-way for bridges and culverts.

U.S. Department of Transportation, 1993, Stream stability and scour at highway bridges, Participant Workbook: Federal Highway Administration Publication FHWA HI-91-011.

U.S. Geological Survey, 1981, South Royalton, Vermont 7.5 Minute Series quadrangle map: U.S. Geological Survey Topographic Maps, Photoinspected 1983, Scale 1:24,000. 


\section{APPENDIX A: \\ WSPRO INPUT FILE}




\section{WSPRO INPUT FILE}

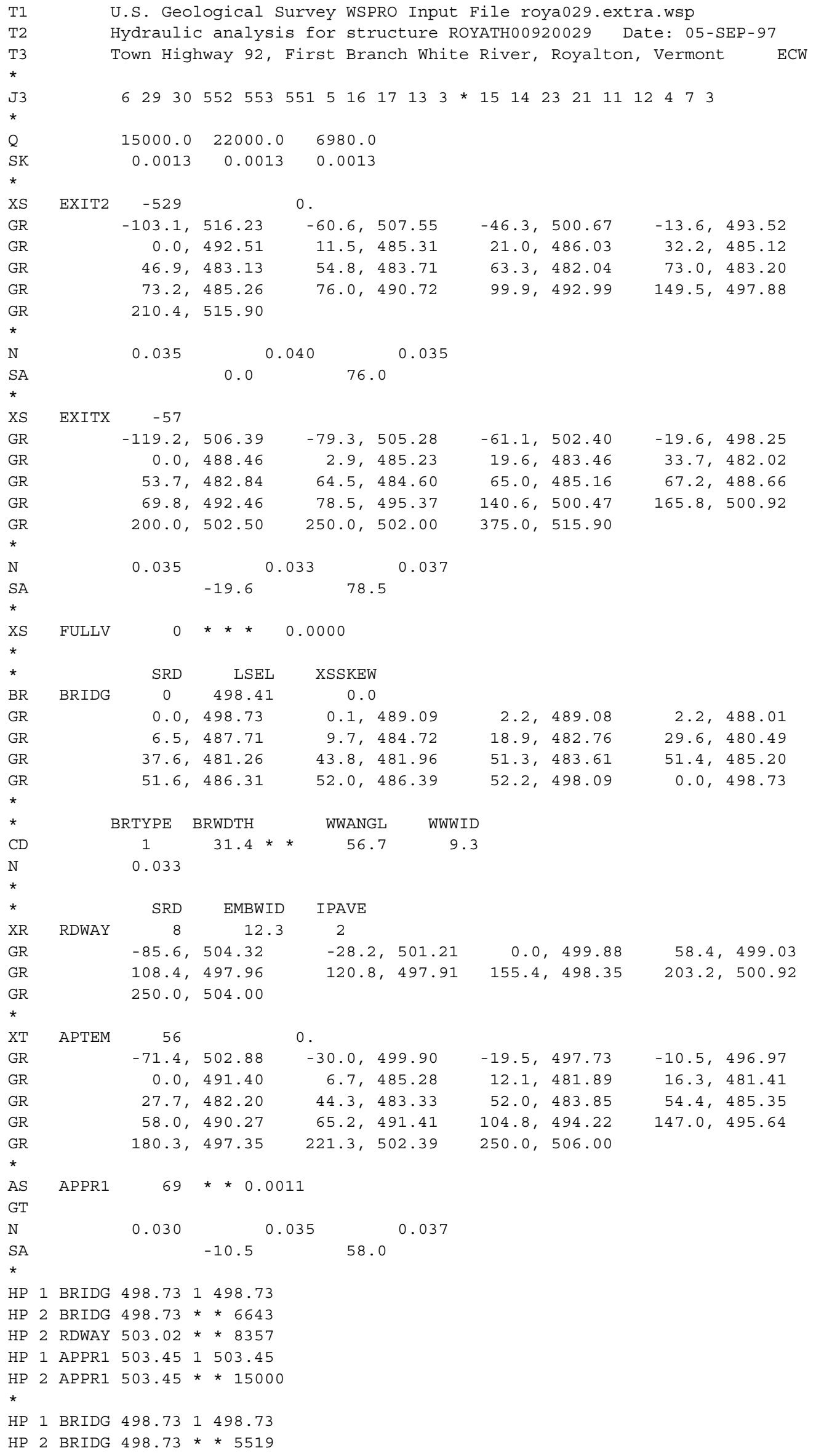




\section{APPENDIX B: \\ WSPRO OUTPUT FILE}


WSPRO OUTPUT FILE

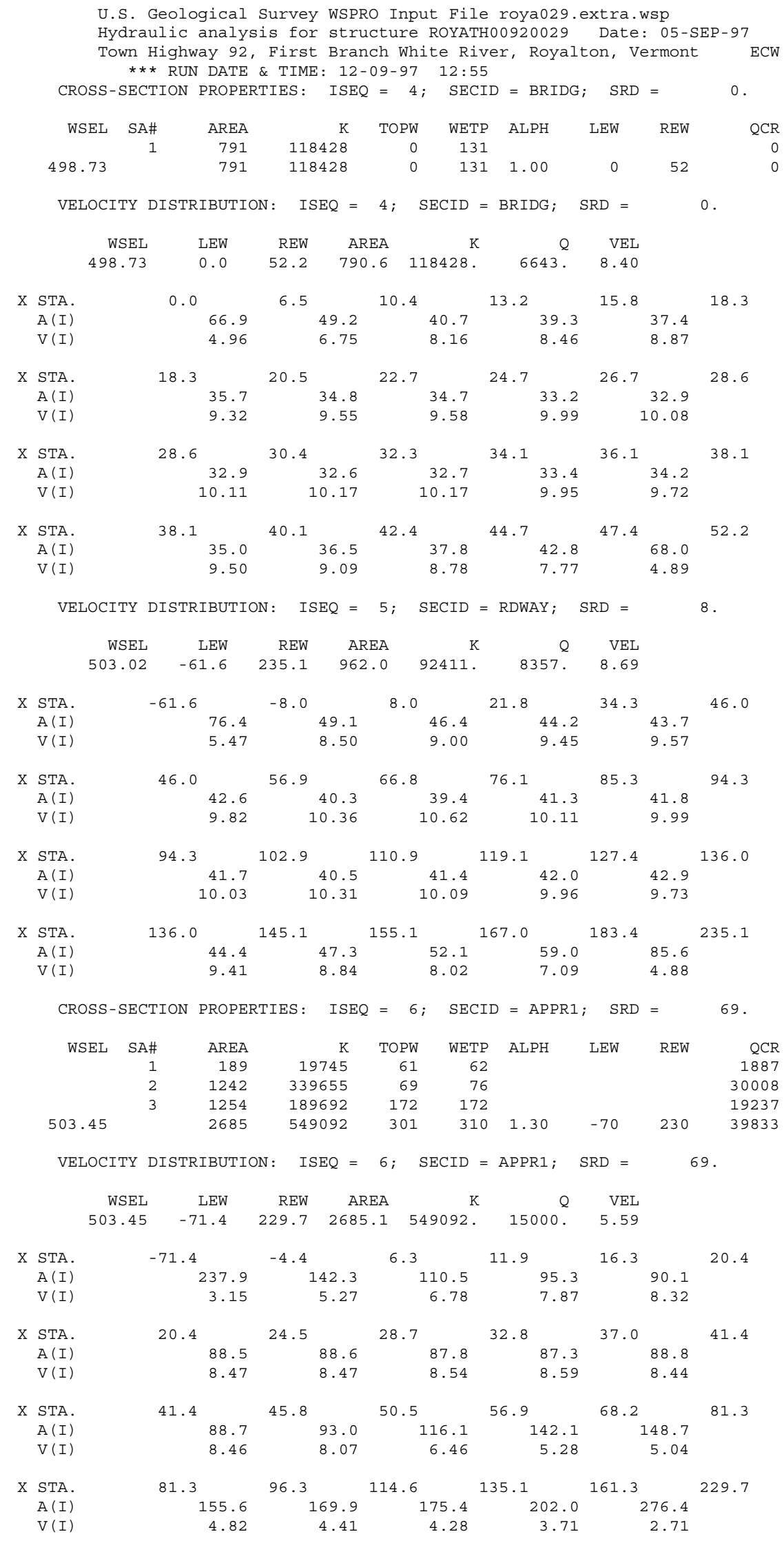


WSPRO OUTPUT FILE (continued)

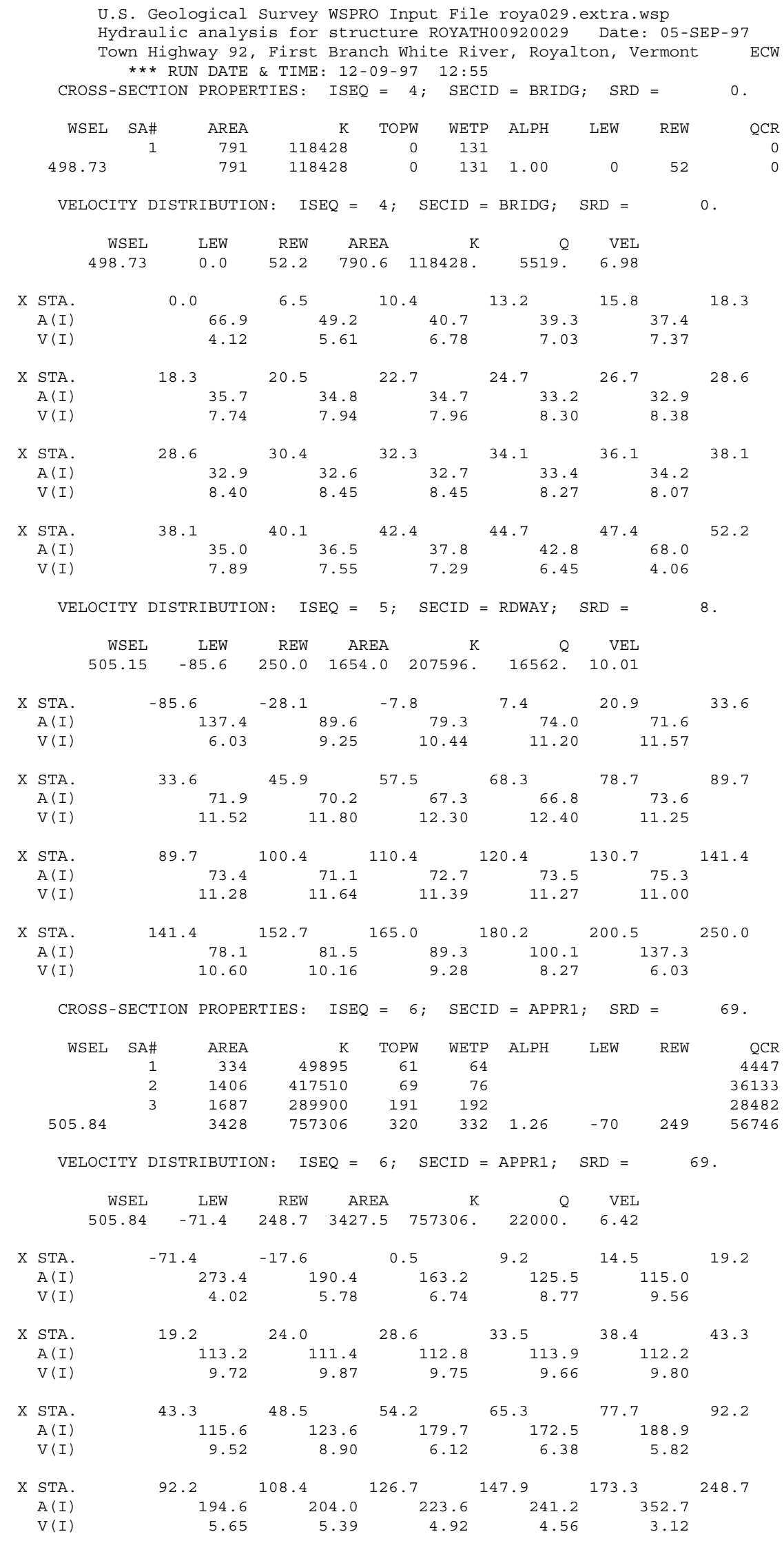


WSPRO OUTPUT FILE (continued)

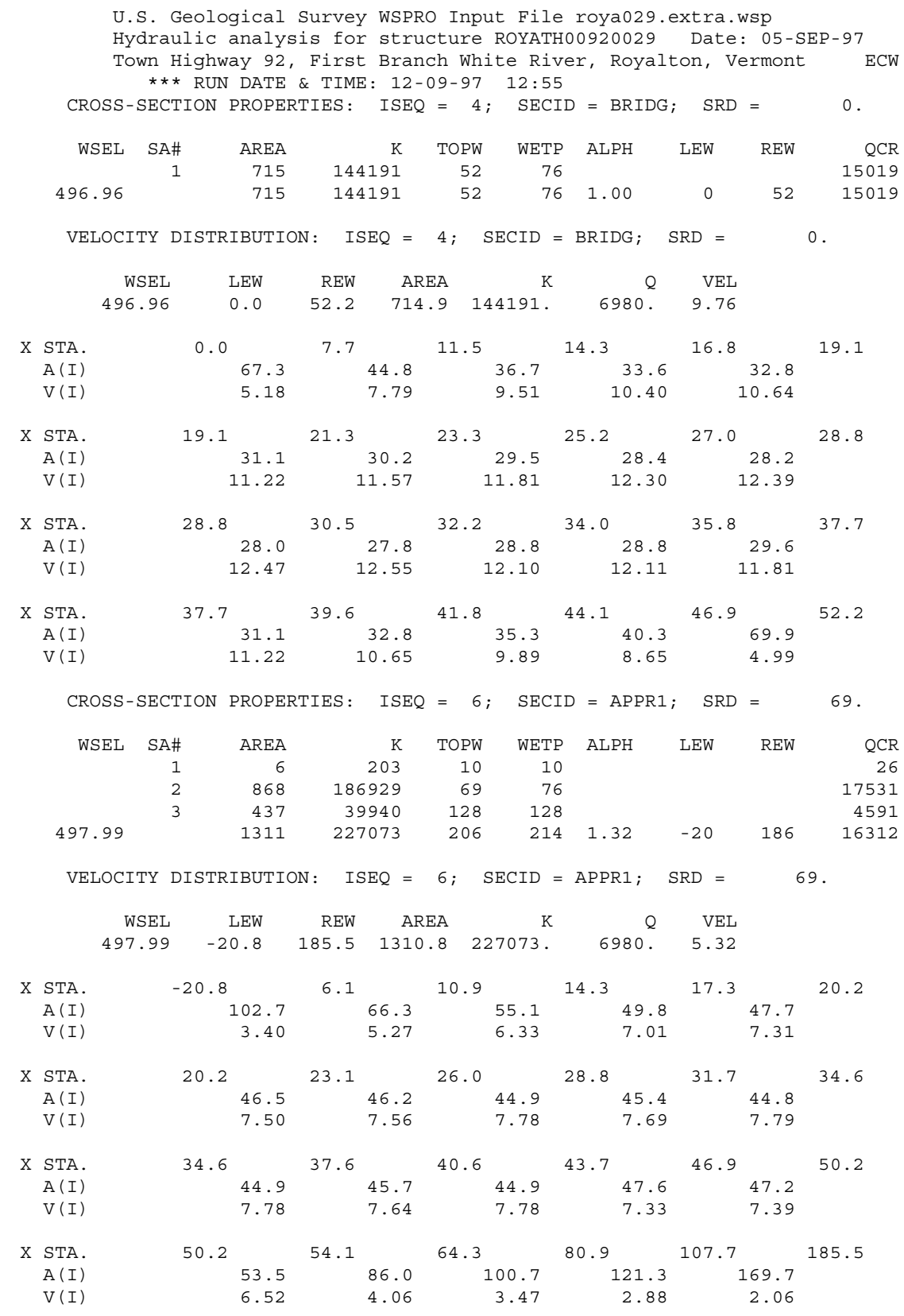


WSPRO OUTPUT FILE (continued)

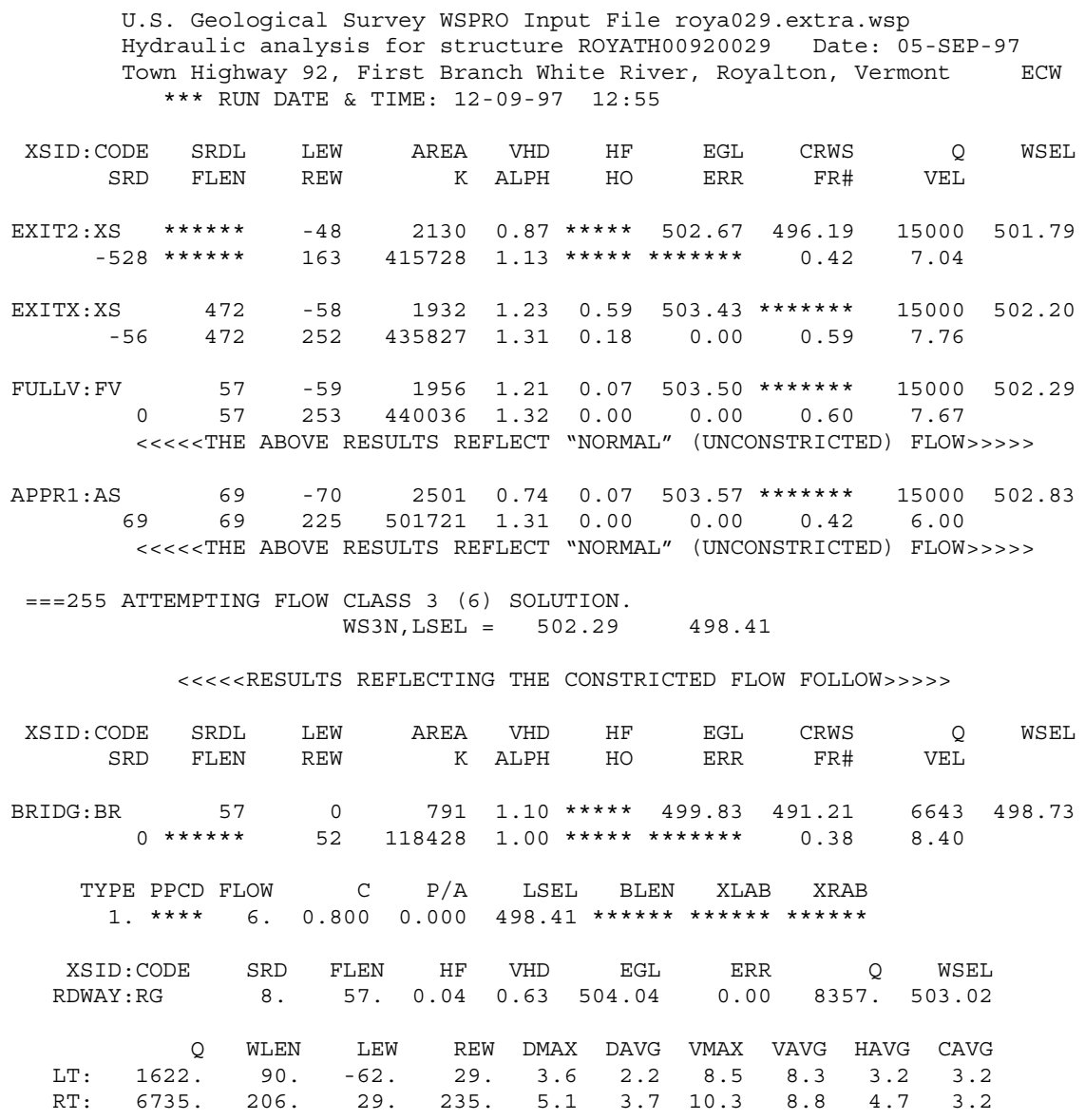

$===140$ AT SECID "APPR1": END OF CROSS SECTION EXTENDED VERTICALLY.

\begin{tabular}{|c|c|c|c|c|c|c|c|c|c|}
\hline \multirow[b]{2}{*}{ XSID: CODE } & \multirow[b]{2}{*}{ SRDL } & \multirow[b]{2}{*}{ LEW } & \multicolumn{2}{|c|}{ WSEL , YLT , YRT } & \multirow[b]{2}{*}{$\mathrm{HF}$} & \multirow{2}{*}{$\begin{array}{r}503.45 \\
\text { EGL }\end{array}$} & \multirow{2}{*}{$\begin{array}{l}502.9 \\
\text { CRWS }\end{array}$} & \multicolumn{2}{|c|}{506.0} \\
\hline & & & AREA & VHD & & & & $Q$ & WSEL \\
\hline SRD & FLEN & REW & K & $\mathrm{ALPH}$ & $\mathrm{HO}$ & ERR & FR\# & VEL & \\
\hline APPR1 : AS & 38 & -70 & 2684 & 0.63 & 0.08 & 504.08 & 497.50 & 15000 & 503.45 \\
\hline 69 & 45 & 230 & 548846 & 1.30 & 0.00 & 0.00 & 0.38 & 5.59 & \\
\hline$M(G)$ & $\mathrm{M}(\mathrm{K})$ & Kס & XLKQ & $\mathrm{XRK}$ & & TEL & & & \\
\hline$\star \star \star \star \star \star \star *$ & $\star \star \star \star \star \star * *$ & $\star \star \star \star \star * \star * \star *$ & $\star \star \star \star \star \star \star \star * *$ & $\star * * *$ & & $\star \star *$ & & & \\
\hline
\end{tabular}

$<<<<$ END OF BRIDGE COMPUTATIONS $>>>>>$

FIRST USER DEFINED TABLE.

\begin{tabular}{|c|c|c|c|c|c|c|c|c|}
\hline XSID : CODE & SRD & LEW & REW & $\mathrm{Q}$ & K & AREA & VEL & WSEL \\
\hline EXIT2:XS & -529. & -49 & 163. & 15000. & 415728 & 2130 & 7.04 & 501.79 \\
\hline EXITX:XS & -57. & -59 & 252 . & 15000 . & 435827 . & 1932. & 7.76 & 502.20 \\
\hline FULLV : FV & 0 . & -60 & 253. & 15000. & 440036 & 1956. & 7.67 & 502.29 \\
\hline BRIDG : BR & 0 . & 0 . & 52. & 6643. & 118428. & 791. & 8.40 & 498.73 \\
\hline RDWAY : RG & 8. * & $\star * \star \star \star *$ & 1622 . & 8357. & $\star \star \star \star \star * \star * \star * *$ & $* * * * * *$ & 2.00 & 503.0 \\
\hline APPR 1 : AS & 69. & -71 & 230 . & 15000. & 548846 & 2684 . & 5.59 & 503.45 \\
\hline XSID : CODE & XLKQ & XRKQ & & & & & & \\
\hline
\end{tabular}

SECOND USER DEFINED TABLE.

$\begin{array}{lrrrrrrrrr}\text { XSID:CODE } & \text { CRWS } & \text { FR\# } & \text { YMIN } & \text { YMAX } & \text { HF } & \text { HO } & \text { VHD } & \text { EGL } & \text { WSEL } \\ \text { EXIT2:XS } & 496.19 & 0.42 & 482.04 & 516.23 * * * * * * * * * * * & 0.87 & 502.67 & 501.79 \\ \text { EXITX:XS } & * * * * * * * * & 0.59 & 482.02 & 515.90 & 0.59 & 0.18 & 1.23 & 503.43 & 502.20 \\ \text { FULLV:FV } & * * * * * * * * & 0.60 & 482.02 & 515.90 & 0.07 & 0.00 & 1.21 & 503.50 & 502.29 \\ \text { BRIDG:BR } & 491.21 & 0.38 & 480.49 & 498.73 * * * * * * * * * * * & 1.10 & 499.83 & 498.73 \\ \text { RDWAY:RG } & * * * * * * * * * * * * * * * * & 497.91 & 504.32 & 0.04 * * * * * * & 0.63 & 504.04 & 503.02 \\ \text { APPR1:AS } & 497.50 & 0.38 & 481.41 & 506.00 & 0.08 & 0.00 & 0.63 & 504.08 & 503.45\end{array}$


WSPRO OUTPUT FILE (continued)

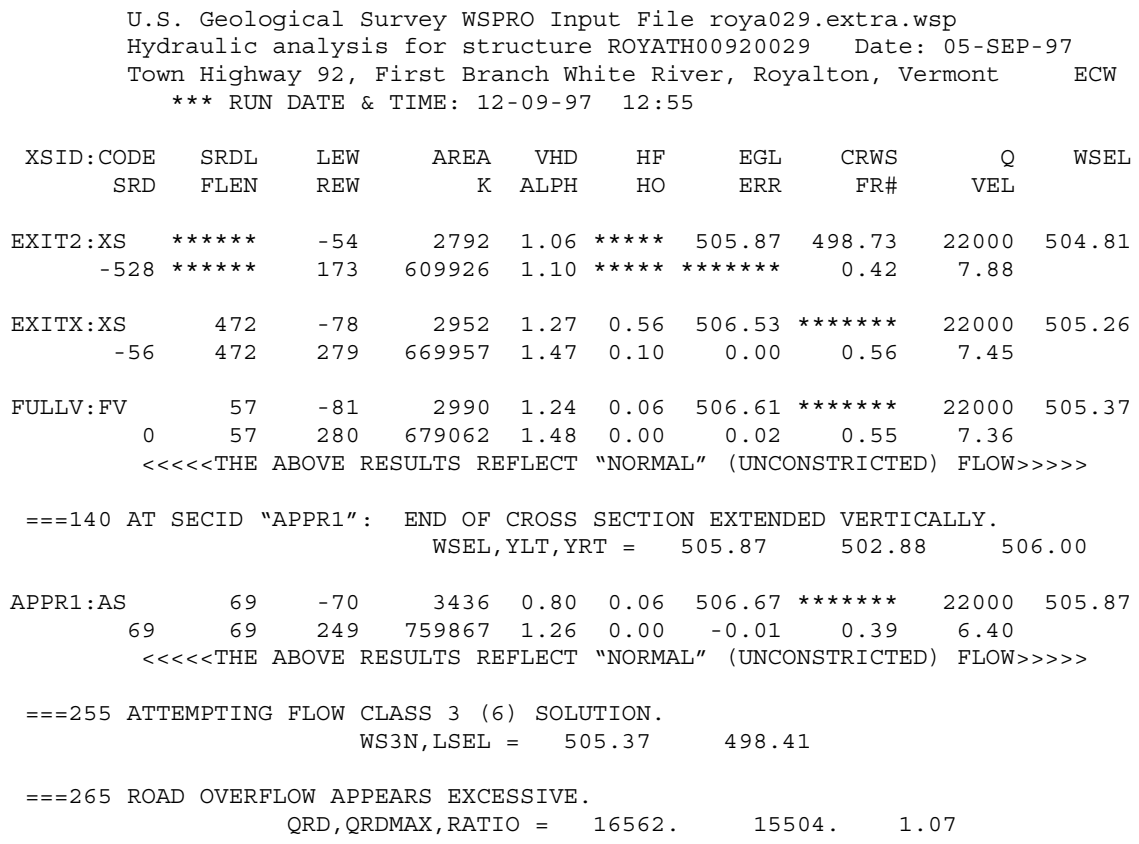

FIRST USER DEFINED TABLE.

\begin{tabular}{|c|c|c|c|c|c|c|c|c|}
\hline XSID : CODE & SRD & LEW & REW & 0 & $\mathrm{~K}$ & AREA & VEL & WSEL \\
\hline EXIT2:XS & -529. & -55 & 173. & 22000 . & 609926 . & 2792 . & 7.88 & 504.81 \\
\hline EXITX:XS & -57 & -79 & 279 . & 22000 & 669957. & 2952. & 7.45 & 505.26 \\
\hline FULLV : FV & 0 . & -82 & 280. & 22000 & 679062 . & 2990. & 7.36 & 505.37 \\
\hline BRIDG : BR & 0 . & 0 . & 52. & 5519. & 118428. & 791. & 6.98 & 498.73 \\
\hline RDWAY : RG & 8. & $\star \star \star \star \star *$ & 4158. & 16562 . & $\star \star \star \star \star \star * \star * \star *$ & $\star \star \star * \star * *$ & 2.00 & 505.15 \\
\hline APPR 1 : AS & 69. & -71 & 249. & 22000 & 757471 & 3428 . & 6.42 & 505.84 \\
\hline CODE & XLKQ & $\mathrm{Q}$ & & & & & & \\
\hline
\end{tabular}

SECOND USER DEFINED TABLE.

$\begin{array}{lcrrrrrrrr}\text { XSID : CODE } & \text { CRWS } & \text { FR\# } & \text { YMIN } & \text { YMAX } & \text { HF } & \text { HO } & \text { VHD } & \text { EGL } & \text { WSEL } \\ \text { EXIT2:XS } & 498.73 & 0.42 & 482.04 & 516.23 * * * * * * * * * * & 1.06 & 505.87 & 504.81 \\ \text { EXITX:XS } & * * * * * * * & 0.56 & 482.02 & 515.90 & 0.56 & 0.10 & 1.27 & 506.53 & 505.26 \\ \text { FULLV:FV } & * * * * * * * * & 0.55 & 482.02 & 515.90 & 0.06 & 0.00 & 1.24 & 506.61 & 505.37 \\ \text { BRIDG:BR } & 490.27 & 0.32 & 480.49 & 498.73 * * * * * * * * * * & 0.76 & 499.49 & 498.73 \\ \text { RDWAY: RG } & * * * * * * * * * * * * * * * * & 497.91 & 504.32 & 0.05 * * * * * * & 0.81 & 506.60 & 505.15 \\ \text { APPR1:AS } & 499.63 & 0.39 & 481.41 & 506.00 & 0.10 & 0.00 & 0.81 & 506.65 & 505.84\end{array}$


WSPRO OUTPUT FILE (continued)

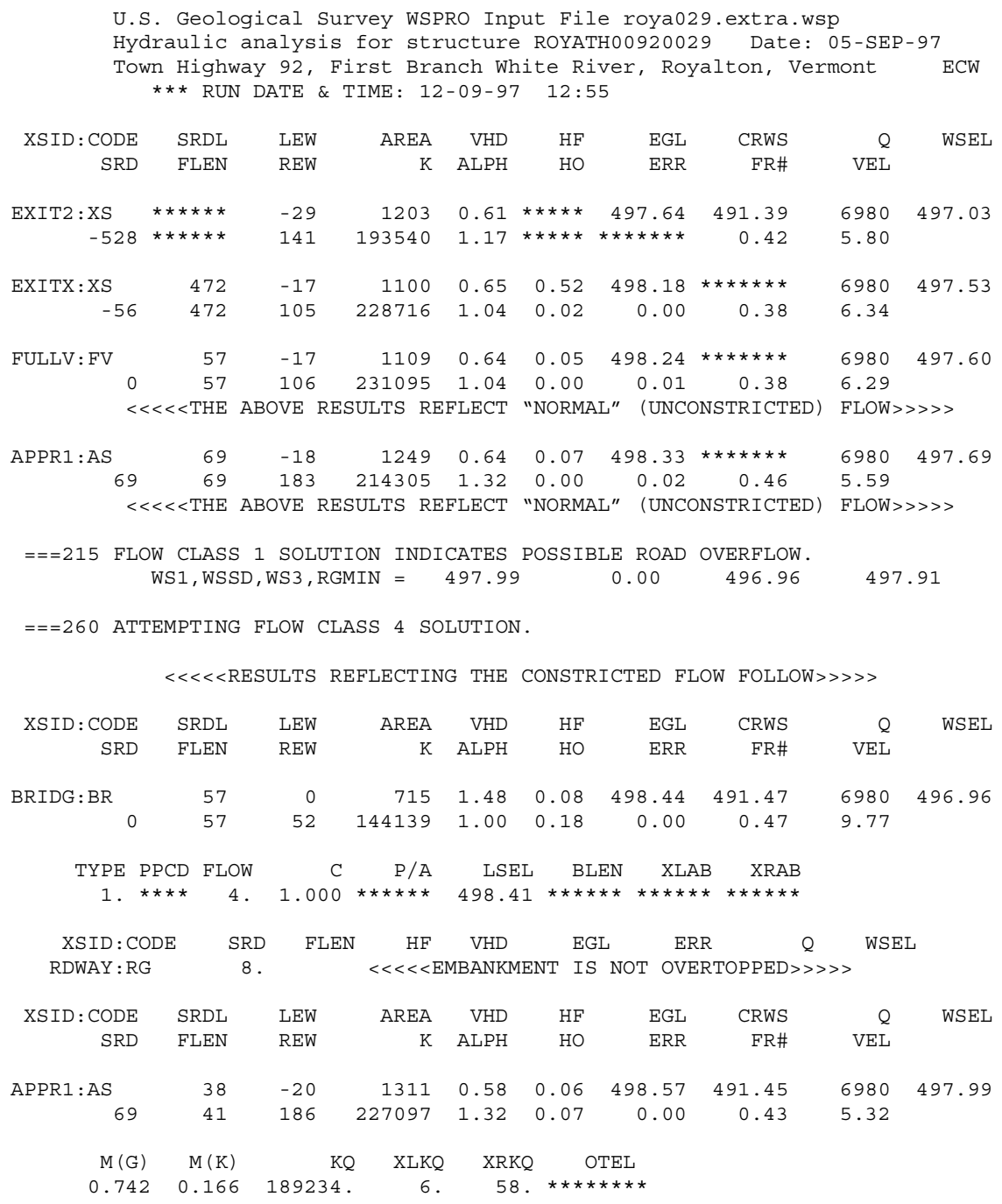

$<<<<<$ END OF BRIDGE COMPUTATIONS $>>>>>$

FIRST USER DEFINED TABLE.

\begin{tabular}{|c|c|c|c|c|c|c|c|c|}
\hline XSID : CODE & SRD & LEW & REW & $Q$ & $\mathrm{~K}$ & AREA & VEL & WSEL \\
\hline EXIT2:XS & -529. & -30 & 141. & 6980. & 193540. & 1203. & 5.80 & 497.03 \\
\hline EXITX:XS & -57. & -18 & 105. & 6980. & 228716 . & 1100. & 6.34 & 497.53 \\
\hline FULLV : FV & 0 . & -18 & 106. & 6980. & 231095 . & 1109. & 6.29 & 497.60 \\
\hline BRIDG : BR & 0 . & 0 . & 52. & 6980. & 144139. & 715. & 9.77 & 496.96 \\
\hline RDWAY : RG & \multicolumn{3}{|c|}{$8 . * * \star * * * * * * \star * * * * *$} & 0 . & 0 . & 0 . & \multicolumn{2}{|c|}{$2.00 * \star * \star * \star * \star *$} \\
\hline APPR1: AS & 69. & -21 & 186. & 6980. & 227097 . & 1311. & 5.32 & 497.99 \\
\hline XSID : CODE & XLKQ & XRKQ & & & & & & \\
\hline APPR $1:$ AS & 6 . & 58. & 189234 & & & & & \\
\hline
\end{tabular}

SECOND USER DEFINED TABLE.

$\begin{array}{lcrrrrrrrr}\text { XSID : CODE } & \text { CRWS } & \text { FR\# } & \text { YMIN } & \text { YMAX } & \text { HF } & \text { HO } & \text { VHD } & \text { EGL } & \text { WSEL } \\ \text { EXIT2:XS } & 491.39 & 0.42 & 482.04 & 516.23 * * * * * * * * * * * & 0.61 & 497.64 & 497.03 \\ \text { EXITX:XS } & * * * * * * * & 0.38 & 482.02 & 515.90 & 0.52 & 0.02 & 0.65 & 498.18 & 497.53 \\ \text { FULLV:FV } & * * * * * * * * & 0.38 & 482.02 & 515.90 & 0.05 & 0.00 & 0.64 & 498.24 & 497.60 \\ \text { BRIDG :BR } & 491.47 & 0.47 & 480.49 & 498.73 & 0.08 & 0.18 & 1.48 & 498.44 & 496.96 \\ \text { RDWAY : RG } & * * * * * * * * * * * * * * * & 497.91 & 504.32 & 0.05 * * * * * * & 0.59 & 498.51 * * * * * * * \\ \text { APPR1:AS } & 491.45 & 0.43 & 481.41 & 506.00 & 0.06 & 0.07 & 0.58 & 498.57 & 497.99 \\ \text { ER } & & & & & & & & & \end{array}$

NORMAL END OF WSPRO EXECUTION. 


\section{APPENDIX C:}

\section{BED-MATERIAL PARTICLE-SIZE DISTRIBUTION}




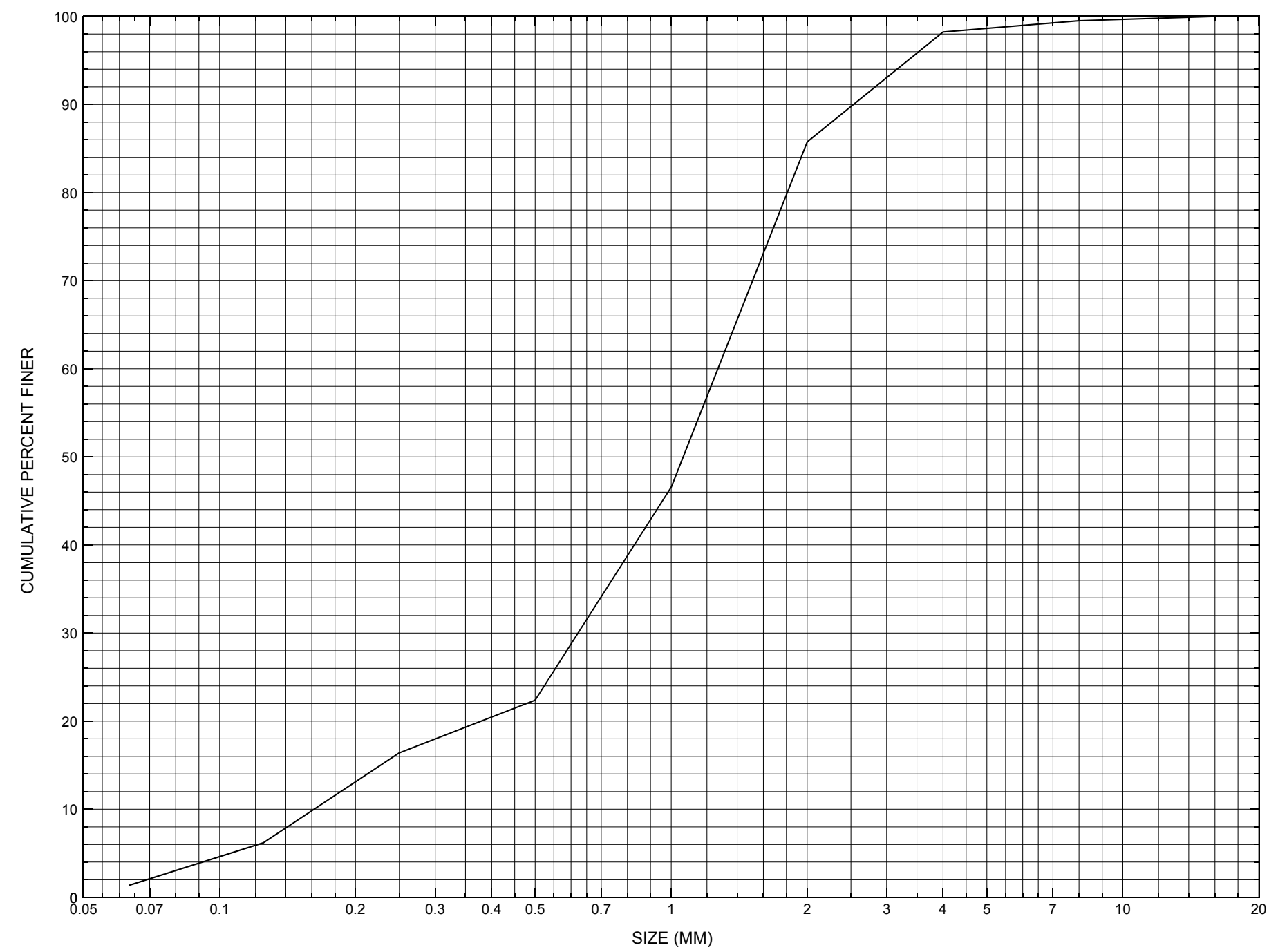

Appendix C. Bed material particle-size distribution for a sieve analysis in the channel approach of structure ROYATH00920029, in Royalton, Vermont. 


\section{APPENDIX D: \\ HISTORICAL DATA FORM}




\section{Structure Number ROYATH00920029}

\section{General Location Descriptive}

Data collected by (First Initial, Full last name) $\mathbf{E}$. BOEHMLER

Date $(M M / D D / Y Y) \_\mathbf{0 3} / \underline{23} / \underline{95}$

Highway District Number (I - 2; nn) $\mathbf{0 4}$

Town (FIPS place code; I - 4; nnnnn) $\mathbf{6 0 8 5 0}$

Waterway ( $($ - 6) FIRST BRANCH WHITE RIVER

Route Number TH092

Topographic Map South Royalton

Latitude (I - 16; nnnn.n) $\mathbf{4 3 5 0 9}$
County (FIPS county code; I - 3; nnn)

Mile marker (I - 11; nnn.nnn) $\mathbf{0 0 0 0 0 0}$

Road Name (I - 7): -

Vicinity (I - 9)@JCT W VT110

Hydrologic Unit Code: $\mathbf{0 1 0 8 0 1 0 5}$

Longitude (i - 17; nnnnn.n) $\mathbf{7 2 3 0 8}$

\section{Select Federal Inventory Codes}

FHWA Structure Number (I - 8) 10141600291416

Maintenance responsibility $(I-21 ; n n) \quad \mathbf{0 3}$

Year built (I - 27; YYYY) 1919

Average daily traffic, ADT (I - 29; nnnnnn) $\underline{000010}$

Year of ADT (I - 30; YY) $\mathbf{9 0}$

Opening skew to Roadway $(I-34 ; n n) \quad \mathbf{0 0}$

Operational status $(I-41 ; X)$ A

Structure type (I - 43; nnn) $\mathbf{3 0 3}$

Approach span structure type $(I-44 ; n n n)$ 000

Number of spans (I - 45; nnn) $\mathbf{0 0 1}$

Number of approach spans (I - 46; nnnn) $\mathbf{0 0 0 0}$

Comments:

The structural inspection report of $6 / 24 / 94$ indicates the structure is a single span, steel stringer type bridge with an asphalt filled corrugated metal deck. Both abutment walls are concrete, which is very clean overall except for some minor spalling on the older right abutment. Both abutment footings are reported as exposed. The right abutment footing has some minor spalling noted. However, no undermining or settling is evident. There is bedrock which outcrops at the base of the left abutment. The waterway is noted as making a moderate bend into the crossing with the left abutment side on the outside of the channel bend. The left abutment is noted as having good stone fill protection placed (Continued, page 33) 


\section{Bridge Hydrologic Data}

Is there hydrologic data available? $\underline{\mathbf{N}}$ if No, type ctrl-n $h \quad$ VTAOT Drainage area $\left(m i^{2}\right)$ : -

Terrain character:

Stream character \& type: -

Streambed material:

Discharge Data (cfs):

$$
\begin{aligned}
& Q_{2.33}- \\
& Q_{50}-
\end{aligned}
$$

Record flood date $(M M / D D / Y Y)$ :

Estimated Discharge (cfs): Ice conditions (Heavy, Moderate, Light) : -

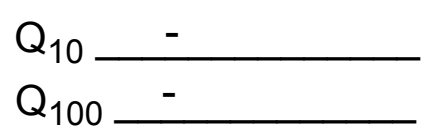

$$
\begin{aligned}
& Q_{25}- \\
& Q_{500}-
\end{aligned}
$$

Water surface elevation $(f t):-$

The stage increases to maximum highwater elevation (Rapidly, Not rapidly):

The stream response is (Flashy, Not flashy):

Describe any significant site conditions upstream or downstream that may influence the stream's stage: -

Watershed storage area (in percent): _ _ \%

The watershed storage area is: - (1-mainly at the headwaters; 2- uniformly distributed; 3-immediatly upstream oi the site)

Water Surface Elevation Estimates for Existing Structure:

\begin{tabular}{|l|l|l|l|l|l|}
\hline Peak discharge frequency & $Q_{2.33}$ & $Q_{10}$ & $Q_{25}$ & $Q_{50}$ & $Q_{100}$ \\
Water surface elevation (ft)) & - & - & - & - & - \\
Velocity (ft/sec) & - & - & - & - & - \\
\hline
\end{tabular}

Long term stream bed changes: -

Is the roadway overtopped below the $\mathrm{Q}_{100}$ ? (Yes, No, Unknown): $\mathbf{U}$ Frequency: Relief Elevation (ft): Discharge over roadway at $Q_{100}\left(f^{3} / \mathrm{sec}\right)$ :

Are there other structures nearby? (Yes, No, Unknown): $\underline{\mathbf{U}}$ Upstream distance (miles): Town: If No or Unknown, type ctrl-n os Highway No. : Structure No. : Year Built:

Clear span (ft): Clear Height $(f t)$ : Full Waterway $\left(f^{2}\right)$ : 
Downstream distance (miles): Town: Year Built:

Highway No. : Structure No. : Structure Type:

Clear span (ft): Clear Height $(f t)$ : Full Waterway $\left(f^{2}\right)$ :

Comments:

along its front. Channel scour, bank erosion, and debris accumulation are reported as not evident. While the footings are exposed, the report indicates the foundation type of the abutments is unknown. The left abutment probably is doweled or sealed into the bedrock.

\section{USGS Watershed Data}

Watershed Hydrographic Data

Drainage area (DA) $101.41 \mathrm{mi}^{2}$

Watershed storage (ST)

Bridge site elevation

Main channel length

490
.89 21.27 $10 \%$ channel length elevation $\quad \mathbf{5 0 0}$

Main channel slope (S) 41.4 $\mathrm{ft} / \mathrm{mi}$

Watershed Precipitation Data

Average site precipitation in Average headwater precipitation in

Maximum 2yr-24hr precipitation event $(124,2)$ in

Average seasonal snowfall (Sn) $\mathrm{ft}$ 


\section{Bridge Plan Data}

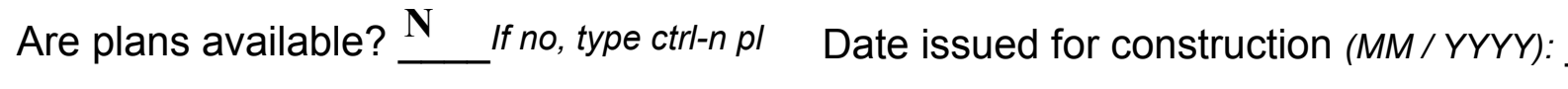

Project Number

Minimum channel bed elevation:

Low superstructure elevation: USLAB DSLAB USRAB DSRAB Benchmark location description:

NO BENCHMARK INFORMATION

$-$

$-$

$-$

Reference Point (MSL, Arbitrary, Other):

Datum (NAD27, NAD83, Other):

Foundation Type: 4

If 1 : Footing Thickness

If 2: Pile Type: (1-Wood; 2-Steel or metal; 3-Concrete)

(1-Spreadfooting; 2-Pile; 3- Gravity; 4-Unknown)

If 3 : Footing bottom elevation:

Is boring information available? $\mathbf{N}$ If no, type ctrl-n bi Number of borings taken:

Foundation Material Type: $\mathbf{3}$ (1-regolith, 2-bedrock, 3-unknown)

Briefly describe material at foundation bottom elevation or around piles:

NO FOUNDATION MATERIAL INFORMATION

Comments:

NO PLANS. 


\section{Cross-sectional Data}

Is cross-sectional data available? Yes If no, type ctrl-n xs

Source (FEMA, VTAOT, Other)? FEMA

Comments:

The station and elevation measurements are in feet.

\begin{tabular}{|c|c|c|c|c|c|c|c|c|c|c|c|}
\hline Station & 1000 & 1009 & 1210 & 1035 & 1055 & - & - & - & - & - & - \\
\hline Feature & LAB & - & - & - & $\mathbf{R A B}$ & - & - & - & - & - & - \\
\hline $\begin{array}{l}\text { Low cord } \\
\text { elevation }\end{array}$ & 502 & 501.8 & 501.6 & 501.4 & 501 & - & - & - & - & - & - \\
\hline $\begin{array}{l}\text { Bed } \\
\text { elevation }\end{array}$ & 493 & 488 & 484 & 484 & 490 & - & - & - & - & - & - \\
\hline $\begin{array}{l}\text { Low cord to } \\
\text { bed length }\end{array}$ & 9 & 13.8 & 17.6 & 17.4 & 11 & - & - & - & - & - & - \\
\hline Station & - & - & - & - & - & - & - & - & - & - & - \\
\hline Feature & - & - & - & - & - & - & - & - & - & - & - \\
\hline $\begin{array}{l}\text { Low cord } \\
\text { elevation }\end{array}$ & - & - & - & - & - & - & - & - & - & - & - \\
\hline $\begin{array}{l}\text { Bed } \\
\text { elevation }\end{array}$ & - & - & - & - & - & - & - & - & - & - & - \\
\hline $\begin{array}{l}\text { Low cord to } \\
\text { bed length }\end{array}$ & - & - & - & - & - & - & - & - & - & - & - \\
\hline
\end{tabular}

Source (FEMA, VTAOT, Other)?

Comments: -

\begin{tabular}{|l|l|l|l|l|l|l|l|l|l|l|l|l|}
\hline Station & - & - & - & - & - & - & - & - & - & - \\
\hline Feature & - & - & - & - & - & - & - & - & - & - \\
\hline $\begin{array}{l}\text { Low cord } \\
\text { elevation }\end{array}$ & - & - & - & - & - & - & - & - & - & - & - \\
\hline $\begin{array}{l}\text { Bed } \\
\text { elevation }\end{array}$ & - & - & - & - & - & - & - & - & - & - \\
\hline $\begin{array}{l}\text { Low cord to } \\
\text { bed length }\end{array}$ & - & - & - & - & - & - & - & - & - & - & - \\
\hline \begin{tabular}{l} 
Station \\
\hline \begin{tabular}{l} 
Feature \\
\hline
\end{tabular}
\end{tabular}$-$ & - & - & - & - & - & - & - & - & - & - \\
\hline $\begin{array}{l}\text { Low cord } \\
\text { elevation }\end{array}$ & - & - & - & - & - & - & - & - & - & - \\
\hline $\begin{array}{l}\text { Bed } \\
\text { elevation }\end{array}$ & - & - & - & - & - & - & - & - & - & - \\
\hline $\begin{array}{l}\text { Low cord to } \\
\text { bed length }\end{array}$ & - & - & - & - & - & - & - & - & - & - \\
\hline
\end{tabular}




\section{APPENDIX E: \\ LEVEL I DATA FORM}


U. S. Geological Survey

Bridge Field Data Collection and Processing Form

Qa/Qc Check by: EW Date: $\underline{\mathbf{1 0} / 16 / 96}$

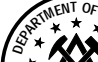

\section{Structure Number}

ROYATH00920029 Computerized by: $\underline{\mathbf{E W}}$ Date: $\underline{\mathbf{1 0} / \mathbf{1 7} / \mathbf{9 6}}$

Reviewd by: $\quad$ EW Date: $9 / 24 / 97$

\section{A. General Location Descriptive}

1. Data collected by (First Initial, Full last name) R. HAMMOND

2. Highway District Number 04

County WINDSOR (027)

Waterway (l - 6) FIRST BRANCH WHITE RIVER

Route Number TH092

3. Descriptive comments:

The bridge is located 50 feet from junction with VT110.
Mile marker $\mathbf{0 0 0 0 0 0}$

Town ROYALTON (60850)

Road Name -

Hydrologic Unit Code: $\mathbf{0 1 0 8 0 1 0 5}$

\section{B. Bridge Deck Observations}

\section{Surface cover... $\quad$ LBUS $4 \quad$ RBUS $4 \quad$ LBDS $4 \quad$ RBDS $4 \quad$ Overall 4}

(2b us,ds,lb,rb: 1- Urban; 2- Suburban; 3- Row crops; 4- Pasture; 5- Shrub- and brushland; 6- Forest; 7- Wetland)

5. Ambient water surface...US $\underline{1}$ UB 1 DS 1 (1-pool; 2- riffle)

6. Bridge structure type 1 (1- single span; 2- multiple span; 3- single arch; 4- multiple arch; 5-cylindrical culvert; 6- box culvert; or 7- other)
7. Bridge length $\mathbf{5 9}$
(feet)
Span length $\underline{\mathbf{5 7}}$
(feet)
Bridge width $\underline{12.3}$ (feet)

\section{Road approach to bridge:}
8. LB 2 RB 1
( 0 even, 1- lower, 2- higher)
9. LB_ 1
RB $\underline{2}$
(1- Paved, 2- Not paved)

10. Embankment slope (run / rise in feet / foot):

US left

US right

\begin{tabular}{|c|c|c|c|}
\hline \multicolumn{2}{|c|}{ Protection } & \multirow{2}{*}{ 13.Erosion } & 14.Severity \\
\hline 11.Type & 12.Cond. & $\underline{\mathbf{2}}$ & $\mathbf{0}$ \\
\hline $\mathbf{0}$ & - & $\underline{\mathbf{2}}$ & $\mathbf{0}$ \\
\hline $\mathbf{0}$ & - & $\underline{\mathbf{2}}$ & $\mathbf{0}$ \\
\hline $\mathbf{0}$ & - & $\underline{\mathbf{2}}$ & $\mathbf{0}$ \\
\hline $\mathbf{0}$ & - & $\underline{\mathbf{0}}$ & - \\
\hline
\end{tabular}

Bank protection types: 0- none; 1- < 12 inches;

2- < 36 inches; 3- < 48 inches;

4- $<60$ inches; 5- wall / artificial levee

Bank protection conditions: 1- good; 2- slumped;

3- eroded; 4- failed

Erosion: 0 - none; 1- channel erosion; 2-

road wash; 3- both; 4- other

Erosion Severity: 0 - none; 1- slight; 2- moderate;

\section{Channel approach to bridge (BF):}

15. Angle of approach: $\mathbf{1 0}$

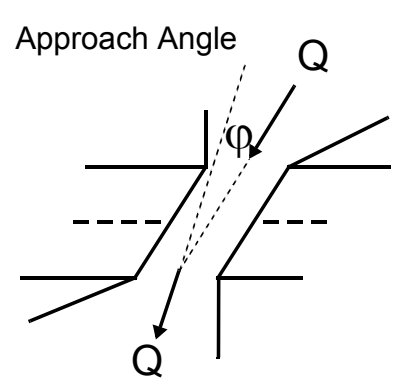

17. Channel impact zone 1 :

Where? LB (LB, RB)

Range? 500 feet US

Channel impact zone 2:

Where? - $(L B, R B)$

Range? - $\quad$ feet -

(US, UB, DS) to feet Impact Severity: 0- none to very slight; 1- Slight; 2- Moderate; 3- Severe

16. Bridge skew: 20 Bridge Skew Angle

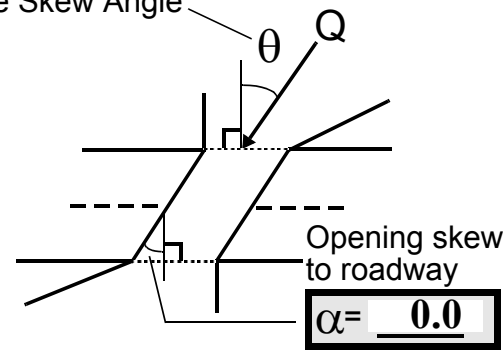

\section{Exist? $\mathbf{Y}(Y$ or $N)$}

Severity $\mathbf{0}$

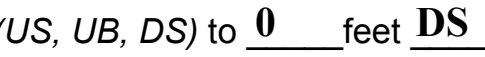

Exist? $\underline{\mathbf{N}}(\mathrm{Y}$ or $N)$

Severity - 
18. Bridge Type: 1a

1a- Vertical abutments with wingwalls

1 b- Vertical abutments without wingwalls

2- Vertical abutments and wingwalls, sloping embankment

Wingwalls parallel to abut. face

3- Spill through abutments

4- Sloping embankment, vertical wingwalls and abutments

1a with wingwalls

Wingwall angle less than $90^{\circ}$.

19. Bridge Deck Comments (surface cover variations, measured bridge and span lengths, bridge type variations, approach overflow width, etc.)

\#7: Values are from the VTAOT database. The measured bridge length $=58.5$ feet; bridge span $=54.7$ feet; and bridge width $=12$ feet within the steel curb.

\section{Upstream Channel Assessment}

\begin{tabular}{|c|c|c|c|c|c|c|c|c|c|c|}
\hline \multicolumn{5}{|c|}{ 21. Bank height (BF) 22. Bank angle (BF) } & \multicolumn{2}{|c|}{ 26. \% Veg. cover (BF) } & \multicolumn{2}{|c|}{ 27. Bank material (BF) } & \multicolumn{2}{|c|}{ 28. Bank erosion (BF } \\
\hline 20. SRD & LB & RB & LB & RB & LB & RB & LB & RB & LB & RB \\
\hline 43.5 & 15.0 & & & 5.0 & 1 & 1 & 5 & 432 & 1 & 1 \\
\hline 23. Ban & & & 24. & el width & 55.0 & 25. $\mathrm{Tr}$ & eg dep & 3.5 & 29. $\mathrm{Bec}$ & 2 \\
\hline
\end{tabular}

30 .Bank protection type:

LB $\underline{2}$

RB 0

31. Bank protection condition: LB 1

$\mathrm{RB}$ -

SRD - Section ref. dist. to US face \% Vegetation (Veg) cover: 1- 0 to 25\%; 2- 26 to 50\%; 3- 51 to $75 \%$; 4- 76 to $100 \%$

Bed and bank Material: 0- organics; 1- silt / clay, < 1/16mm; 2- sand, 1/16 - 2mm; 3- gravel, 2 - 64mm;

4- cobble, 64 - 256mm; 5- boulder, > 256mm; 6- bedrock; 7- manmade

Bank Erosion: 0- not evident; 1- light fluvial; 2- moderate fluvial; 3- heavy fluvial / mass wasting

Bank protection types: 0- absent; 1- < 12 inches; 2- < 36 inches; 3- < 48 inches; 4- < 60 inches; 5- wall / artificial levee

Bank protection conditions: 1-good; 2- slumped; 3- eroded; 4- failed

32. Comments (bank material variation, minor inflows, protection extent, etc.):

\#30: Left bank road protection for Vermont 110 extends from bridge to at least 500 feet upstream. Boulders are sparce along the bank. 
36. Point bar extent: $\underline{\mathbf{5 0 0}}$ feet $\underline{\mathbf{U S}}$ (US, UB) to $\underline{\mathbf{5}}$ feet $\underline{\mathrm{US}}$ (US, UB, DS) positioned $\underline{\mathbf{8 0}} \%$ LB to $\underline{\mathbf{1 0 0}} \%$

37. Material: 2

38. Point or side bar comments (Circle Point or Side; Note additional bars, material variation, status, etc.):

Point bar.

39. Is a cut-bank present? $\mathbf{N}$ ( $Y$ or if $N$ type ctrl-n $c b)$

40. Where? - $\quad(L B$ or $R B)$

41. Mid-bank distance: -

42. Cut bank extent: -

feet -

(US, UB) to feet (US, UB, DS)

43. Bank damage: (1- eroded and/or creep; 2- slip failure; 3- block failure)

44. Cut bank comments (eg. additional cut banks, protection condition, etc.):

NO CUT BANKS

45. Is channel scour present? $\mathbf{Y}$ ( $Y$ or if $N$ type ctrl-n cs) $\quad$ 46. Mid-scour distance: 15

47. Scour dimensions: Length $\underline{65}$ Width $\underline{15}$ Depth: $\underline{4} \quad$ Position $\underline{40} \%$ LB to $\underline{\mathbf{7 0}}$ \%RB

48. Scour comments (eg. additional scour areas, local scouring process, etc.):

The average thalweg near bridge is $\mathbf{4}$ feet.

The scour hole extends from $\mathbf{7 0}$ feet upstream to 5 feet upstream.

49. Are there major confluences? $\mathbf{N}$ (Y or if $N$ type ctrl-n $m c$ )

51. Confluence 1: Distance Confluence 2: Distance 52. Enters on Enters on ( $L B$ or $R B)$ (LB or $R B)$

54. Confluence comments (eg. confluence name):

NO MAJOR CONFLUENCES

\section{NO MAJOR CONFLUENCES}

50. How many? -

53. Type(1-perennial; 2- ephemeral)

Type (1-perennial; 2- ephemeral)

\section{Under Bridge Channel Assessment}

55. Channel restraint (BF)? LB 2

\begin{tabular}{|cccc}
\hline \multicolumn{2}{|c}{ 56. Height (BF) } & \multicolumn{2}{c}{57 Angle (BF) } \\
LB & RB & LB & RB \\
$\mathbf{4 2 . 5}$ & & 4.0 &
\end{tabular}

58. Bank width (BF) (1- natural bank; 2- abutment; 3- artificial levee)

Bed and bank Material: 0- organics; 1- silt / clay, < 1/16mm; 2- sand, 1/16 - 2mm; 3- gravel, 2 - 64mm; 4- cobble, 64 - 256mm; 5- boulder, > 256mm; 6- bedrock; 7- manmade

Bank Erosion: 0- not evident; 1- light fluvial; 2- moderate fluvial; 3- heavy fluvial / mass wasting

64. Comments (bank material variation, minor inflows, protection extent, etc.):

621 
65. Debris and Ice Is there debris accumulation?

67. Debris Potential $\underline{1}$ ( 1- Low; 2- Moderate; 3- High)

69. Is there evidence of ice build-up? 1

70. Debris and Ice Comments:
$(Y$ or $N)$ 66. Where? $\mathbf{Y}$

68. Capture Efficiency 1

(1- Upstream; 2- At bridge; 3-Both)

Ice Blockage Potential $\mathbf{N}$
(1- Low; 2- Moderate; 3- High)

(1-Low; 2- Moderate; 3- High) 1

\begin{tabular}{|l|c|c|c|c|c|c|c|c|}
\hline Abutments & $\begin{array}{c}\text { 71. Attack } \\
\angle \text { (BF) }\end{array}$ & $\begin{array}{c}72 \text {. Slope } \angle \\
\text { (Qmax) }\end{array}$ & $\begin{array}{c}\text { 73. Toe } \\
\text { loc. (BF) }\end{array}$ & $\begin{array}{c}\text { 74. Scour } \\
\text { Condition }\end{array}$ & $\begin{array}{c}\text { 75. Scour } \\
\text { depth }\end{array}$ & $\begin{array}{c}\text { 76. Exposure } \\
\text { depth }\end{array}$ & 77. Material & 78. Length \\
\hline LABUT & & $\mathbf{0}$ & $\mathbf{9 0}$ & $\mathbf{2}$ & $\mathbf{0}$ & - & - & $\mathbf{9 0 . 0}$ \\
\hline RABUT & $\mathbf{1}$ & $\mathbf{0}$ & $\mathbf{9 0}$ & & & $\mathbf{2}$ & $\mathbf{3}$ & $\mathbf{5 2 . 0}$ \\
\hline
\end{tabular}

Pushed: $L B$ or RB

Toe Location (Loc.): 0- even, 1- set back, 2- protrudes

Scour cond.: 0- not evident; 1- evident (comment); 2- footing exposed; 3-undermined footing; 4- piling exposed; 5- settled; 6- failed

Materials: 1- Concrete; 2- Stone masonry or drywall; 3- steel or metal; 4- wood

79. Abutment comments (eg. undermined penetration, unusual scour processes, debris, etc.):

0

3

1

\#74: The RABUT footing can be penetrated 2 feet at the downstream end, and 1.5 feet in the middle of the abutment. The upstream end of the footing can not be penetrated.

80. Wingwalls:

Exist? Material? Scour Scour Exposure $\begin{aligned} & 81 . \\ & \text { Angle? Length? }\end{aligned}$ Condition? depth? depth?

USLWW:

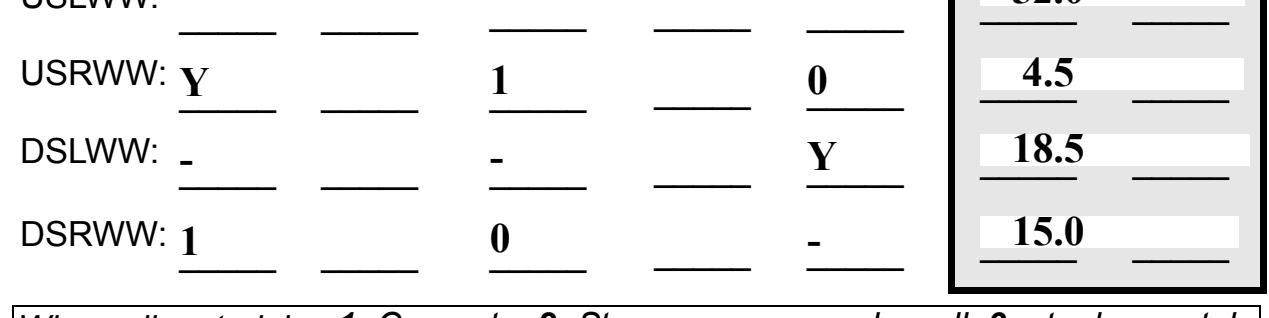

Wingwall materials: 1- Concrete; 2- Stone masonry or drywall; 3- steel or metal; 4- wood

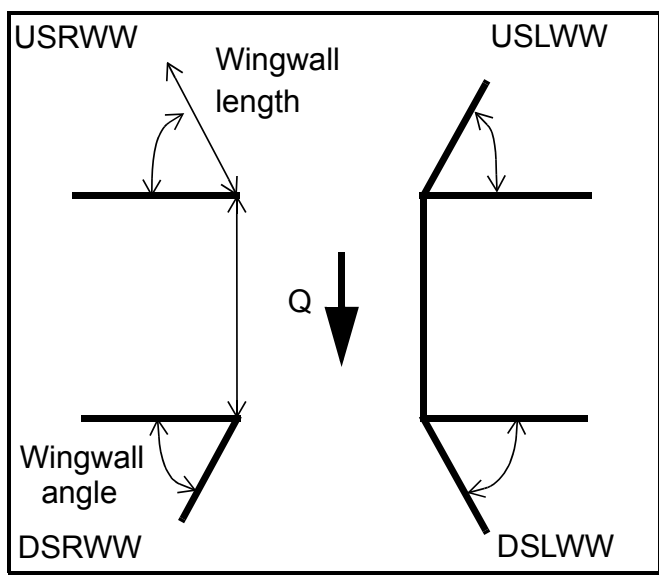

82. Bank / Bridge Protection:

\begin{tabular}{|l|l|l|l|l|l|l|l|l|}
\hline Location & USLWW & USRWW & LABUT & RABUT & LB & RB & DSLWW & DSRWW \\
\hline Type & - & $\mathbf{0}$ & $\mathbf{Y}$ & - & $\mathbf{1}$ & $\mathbf{1}$ & $\mathbf{1}$ & - \\
\hline Condition & $\mathbf{Y}$ & - & $\mathbf{1}$ & - & $\mathbf{1}$ & $\mathbf{1}$ & $\mathbf{1}$ & - \\
\hline Extent & $\mathbf{1}$ & - & $\mathbf{0}$ & $\mathbf{2}$ & $\mathbf{2}$ & $\mathbf{2}$ & $\mathbf{0}$ & - \\
\hline
\end{tabular}

Bank / Bridge protection types: 0- absent; 1- < 12 inches; 2- < 36 inches; 3- < 48 inches; 4- < 60 inches; 
83. Wingwall and protection comments (eg. undermined penetration, unusual scour processes, etc.):

-
-
-
-
-
2
1
1
0
-
-

\section{Piers:}

84. Are there piers? _ _ (Y or if $N$ type ctrl-n pr)

\begin{tabular}{|l|l|l|l|l|l|l|l|}
\hline \multirow{2}{*}{$\begin{array}{l}85 . \\
\text { Pier no. }\end{array}$} & \multicolumn{3}{|c|}{ width (w) feet } & \multicolumn{3}{c|}{ elevation (e) feet } \\
\cline { 2 - 8 } & w1 & w2 & w3 & e@w1 & e@w2 & e@w3 \\
\hline Pier 1 & & & & $\mathbf{7 0 . 0}$ & $\mathbf{1 9 . 0}$ & $\mathbf{4 0 . 0}$ \\
\hline Pier 2 & & & & $\mathbf{1 7 . 0}$ & $\mathbf{6 0 . 0}$ & $\mathbf{1 0 . 0}$ \\
\hline Pier 3 & & & - & $\mathbf{4 0 . 0}$ & $\mathbf{1 3 . 0}$ & - \\
\hline Pier 4 & - & - & - & - & - & - \\
Nyyyy
\end{tabular}

\begin{tabular}{|c|c|c|c|c|}
\hline Level 1 Pier Descr. & 1 & 2 & 3 & 4 \\
\hline 86. Location (BF) & & - & - & - \\
\hline 87. Type & & - & - & - \\
\hline 88. Material & & - & - & - \\
\hline 89. Shape & & - & - & - \\
\hline 90. Inclined? & & - & - & - \\
\hline 91. Attack $\angle(\mathrm{BF})$ & & - & - & - \\
\hline 92. Pushed & & - & - & - \\
\hline 93. Length (feet) & - & - & - & - \\
\hline 94. \# of piles & & - & - & - \\
\hline 95. Cross-members & & - & - & - \\
\hline 96. Scour Condition & & - & - & - \\
\hline 97. Scour depth & $\mathbf{N}$ & - & - & - \\
\hline 98. Exposure depth & - & - & - & - \\
\hline
\end{tabular}

LFP, LTB, LB, MCL, MCM, MCR, RB, RTB, RFP

1- Solid pier, 2- column, 3- bent

1-Wood; 2- concrete; 3- metal; 4- stone

1- Round; 2- Square; 3- Pointed

Y-yes; $N$ - no

$L B$ or $R B$

0- none; 1- laterals; 2- diagonals; 3- both

0- not evident; 1- evident (comment);

2- footing exposed; 3- piling exposed;

4- undermined footing; 5- settled; 6- failed 
99. Pier comments (eg. undermined penetration, protection and protection extent, unusual scour processes, etc.):

-
-
-
-
-
-
-
-
-
-

100.

\section{E. Downstream Channel Assessment}

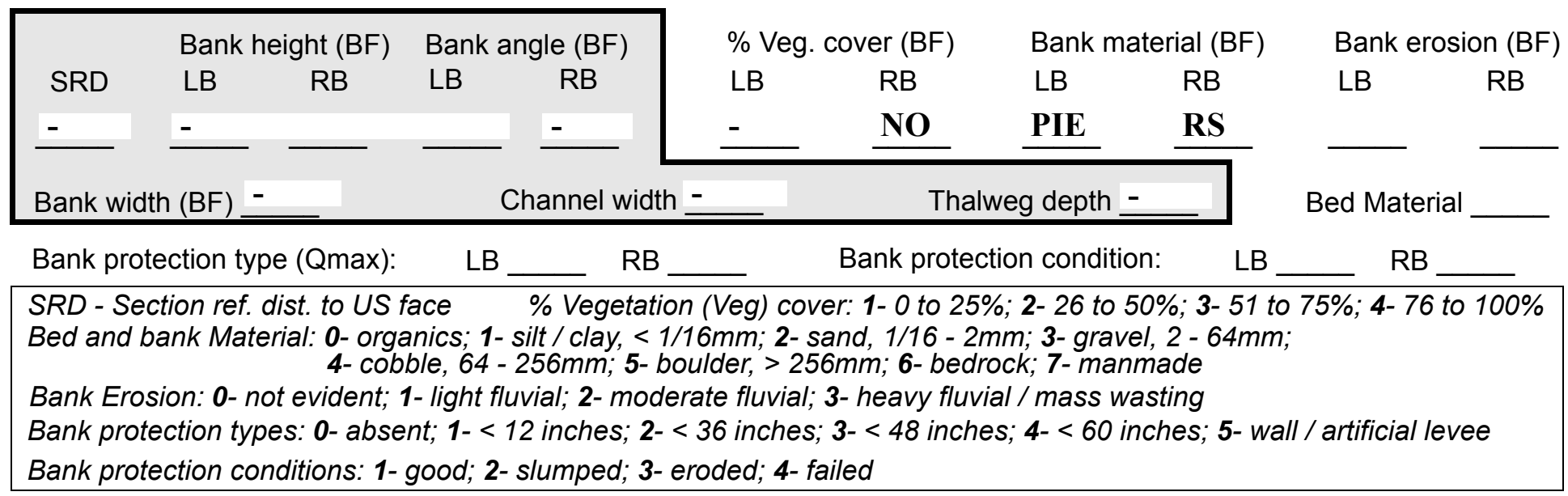

Comments (eg. bank material variation, minor inflows, protection extent, etc.):

1
2
5
2
2
1
2
0
0
-
-

There are some naturally placed boulders along the left bank.

101. Is a drop structure present? ___ ( or $N$, if $N$ type ctrl-n ds) 102. Distance: ___ feet
103. Drop: - feet
104. Structure material:
(1- steel sheet pile; 2- wood pile; 3-concrete; 4- other)

105. Drop structure comments (eg. downstream scour depth): 
Point bar extent: feet

(US, UB, DS) to $\underline{\mathbf{N}}$ feet (US, UB, DS)

DS) positioned \%LB to DR \%RB

Material: $\mathbf{O P}$

Point or side bar comments (Circle Point or Side; note additional bars, material variation, status, etc.):

\section{STRUCTURE}

Is a cut-bank present? (Y or if $N$ type ctrl-n cb) Where? (LB or $R B)$

Mid-bank distance: $\underline{\mathbf{N}}$

Cut bank extent: feet (US, UB, DS) to feet (US, UB, DS)

Bank damage: (1- eroded and/or creep; 2- slip failure; 3- block failure)

Cut bank comments (eg. additional cut banks, protection condition, etc.):

-

$-$

$-$

$-$

Is channel scour present? NO (Y or if $N$ type ctrl-n cs) Mid-scour distance: $\underline{\text { POIN }}$

Scour dimensions: Length $\underline{\mathbf{T}}$ Width $\underline{\text { BAR }}$ Depth: $\underline{\mathbf{S}}$ Positioned __ $\%$ LB to _ $\%$ RB

Scour comments (eg. additional scour areas, local scouring process, etc.):

$\mathbf{Y}$

LB

45

Are there major confluences? $\mathbf{0}$ (Y or if $N$ type ctrl- $n$ mc) How many? $\underline{\mathbf{D S}}$

Confluence 1: Distance $\mathbf{7 0}$ Enters on $\underline{\text { DS }}$ ( $L B$ or $R B)$

Type 1 (1- perennial; 2- ephemeral)

Confluence 2: Distance

Enters on (LB or RB)

Type (1- perennial; 2- ephemeral)

Confluence comments (eg. confluence name):

$\mathbf{N}$

\section{F. Geomorphic Channel Assessment}

107. Stage of reach evolution -

1- Constructed

2- Stable

3- Aggraded

4- Degraded

5- Laterally unstable

6- Vertically and laterally unstable 
108. Evolution comments (Channel evolution not considering bridge effects; See HEC-20, Figure 1 for geomorphic descriptors):

$-$

$-$

$-$

$-$

$-$

NO CHANNEL SCOUR

$\mathbf{N}$

$-$

$-$

$-$ 


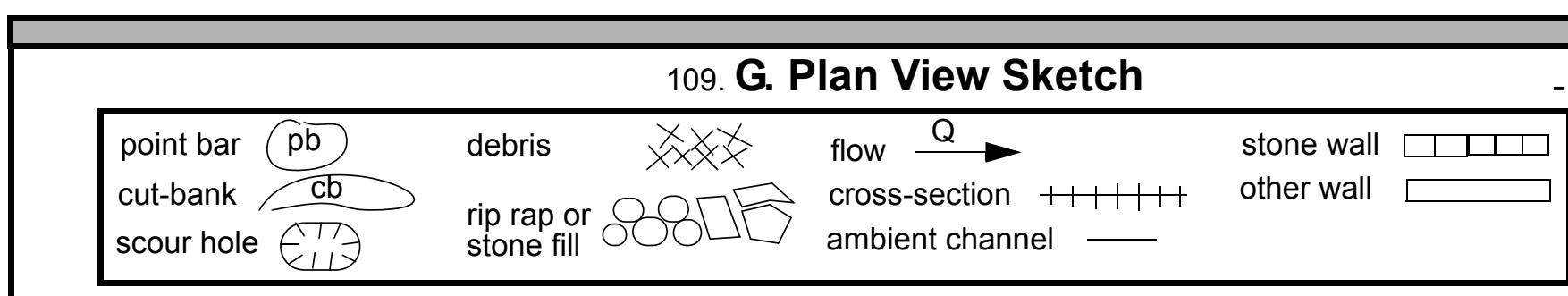


APPENDIX F:

SCOUR COMPUTATIONS 


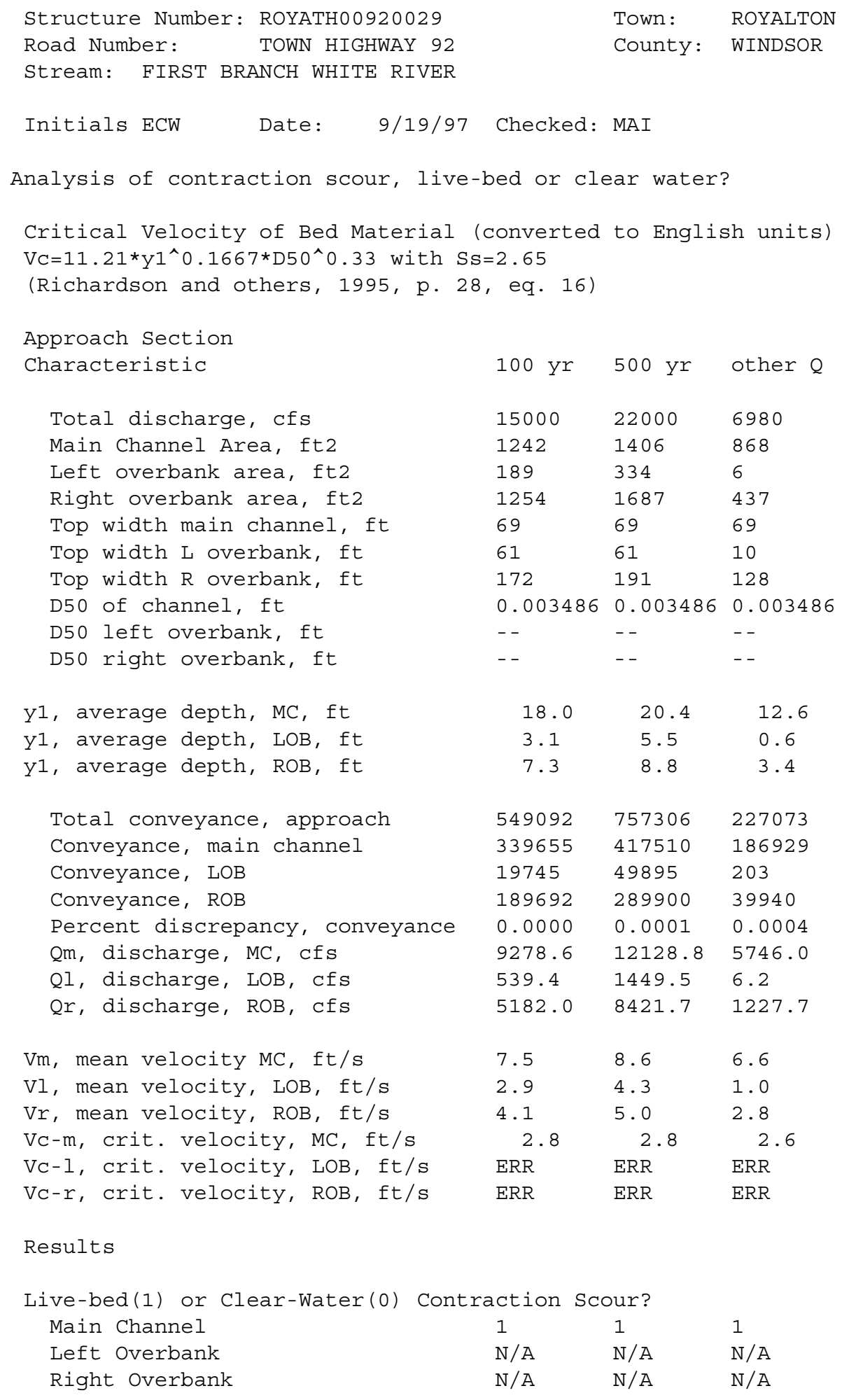

\begin{tabular}{|c|c|c|}
\hline $100 \mathrm{yr}$ & $500 \mathrm{yr}$ & other Q \\
\hline 15000 & 22000 & 6980 \\
\hline 1242 & 1406 & 868 \\
\hline 189 & 334 & 6 \\
\hline 1254 & 1687 & 437 \\
\hline 69 & 69 & 69 \\
\hline 61 & 61 & 10 \\
\hline 172 & 191 & 128 \\
\hline 0.003486 & 0.003486 & 0.003486 \\
\hline-- & -- & -- \\
\hline-- & -- & -- \\
\hline 18.0 & 20.4 & 12.6 \\
\hline 3.1 & 5.5 & 0.6 \\
\hline 7.3 & 8.8 & 3.4 \\
\hline 549092 & 757306 & 227073 \\
\hline 339655 & 417510 & 186929 \\
\hline 19745 & 49895 & 203 \\
\hline 189692 & 289900 & 39940 \\
\hline 0.0000 & 0.0001 & 0.0004 \\
\hline 9278.6 & 12128.8 & 5746.0 \\
\hline 539.4 & 1449.5 & 6.2 \\
\hline 5182.0 & 8421.7 & 1227.7 \\
\hline 7.5 & 8.6 & 6.6 \\
\hline 2.9 & 4.3 & 1.0 \\
\hline 4.1 & 5.0 & 2.8 \\
\hline 2.8 & 2.8 & 2.6 \\
\hline $\mathrm{ERR}$ & $E R R$ & ERR \\
\hline $\mathrm{ERR}$ & ERR & ERR \\
\hline action Sc & our? & \\
\hline 1 & 1 & 1 \\
\hline $\mathrm{N} / \mathrm{A}$ & $\mathrm{N} / \mathrm{A}$ & $\mathrm{N} / \mathrm{A}$ \\
\hline $\mathrm{N} / \mathrm{A}$ & $\mathrm{N} / \mathrm{A}$ & $\mathrm{N} / \mathrm{A}$ \\
\hline
\end{tabular}




\begin{tabular}{|c|c|c|c|c|c|c|}
\hline \multicolumn{7}{|c|}{$\begin{array}{l}\text { Laursen's Live Bed Contraction Scour } \\
\mathrm{y} 2 / \mathrm{y} 1=(\mathrm{Q} 2 / \mathrm{Q} 1)^{\wedge}(6 / 7) *(\mathrm{~W} 1 / \mathrm{W} 2)^{\wedge}(\mathrm{k} 1) \\
\mathrm{ys}=\mathrm{y} 2-\mathrm{y} \text { bridge } \\
\text { (Richardson and others, 1995, p. } 30, \text { eq. } 17 \text { and } 18)\end{array}$} \\
\hline & Approach & & & Bridge & & \\
\hline Characteristic & $100 \mathrm{yr}$ & 500 yr & Other $Q$ & $100 \mathrm{yr}$ & $500 \mathrm{yr}$ & Other Q \\
\hline Q1, discharge, cfs & 15000 & 22000 & 6980 & 6643 & 5519 & 6980 \\
\hline Total conveyance & 549092 & 757306 & 227073 & 118428 & 118428 & 144191 \\
\hline Main channel conveyance & 339655 & 417510 & 186929 & 118428 & 118428 & 144191 \\
\hline Main channel discharge & 9279 & 12129 & 5746 & 6643 & 5519 & 6980 \\
\hline Area - main channel, ft2 & 1242 & 1406 & 868 & 791 & 791 & 715 \\
\hline (W1) channel width, ft & 69 & 69 & 69 & 52.2 & 52.2 & 52.2 \\
\hline (Wp) cumulative pier width, ft & 0 & 0 & 0 & 0 & 0 & 0 \\
\hline w1, adjusted bottom width(ft) & 69 & 69 & 69 & 52.2 & 52.2 & 52.2 \\
\hline D50, ft & 0.003486 & 50.003486 & 60.003486 & & & \\
\hline w, fall velocity, ft/s (p. 32) & 0.45826 & 0.45826 & 0.45826 & & & \\
\hline y, ave. depth flow, ft & 18.00 & 20.38 & 12.58 & 15.15 & 15.15 & 13.70 \\
\hline S1, slope EGL & 0.001 & 0.00087 & 0.0013 & & & \\
\hline$P$, wetted perimeter, $M C$, ft & 76 & 76 & 76 & & & \\
\hline R, hydraulic Radius, ft & 16.342 & 18.500 & 11.421 & & & \\
\hline $\mathrm{V}^{*}$, shear velocity, ft/s & 0.725 & 0.720 & 0.691 & & & \\
\hline $\mathrm{V} * / \mathrm{w}$ & 1.583 & 1.571 & 1.509 & & & \\
\hline $\begin{array}{l}\text { Bed transport coeff., } \mathrm{k} 1,(0.59 \text { if } \\
\mathrm{k} 1\end{array}$ & $\begin{array}{l}\mathrm{V}^{*} / \mathrm{w}<0.5 \\
0.64\end{array}$ & $\begin{array}{l}0.64 \text { if. } \\
0.64\end{array}$ & $\begin{array}{l}.5<\mathrm{V}^{*} / \mathrm{w}<2 \\
0.64\end{array}$ & ; 0.69 if & $\mathrm{V} * / \mathrm{w}>2.0$ & $0 \mathrm{p} .33)$ \\
\hline y2, depth in contraction, ft & 16.16 & 12.40 & 17.77 & & & \\
\hline ys, scour depth, ft (y2-y & 1.01 & -2.75 & 4.07 & & & \\
\hline
\end{tabular}




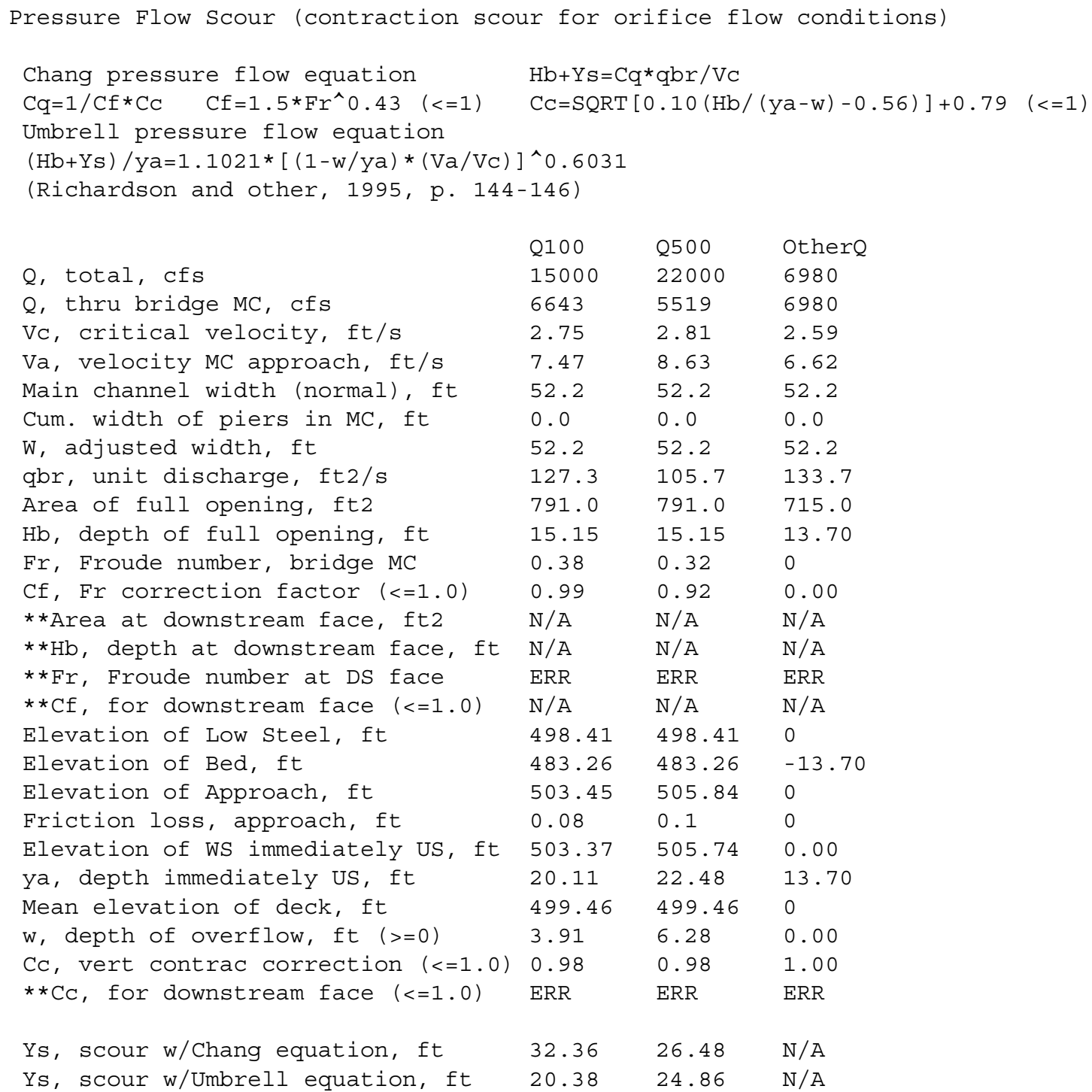

Armoring 


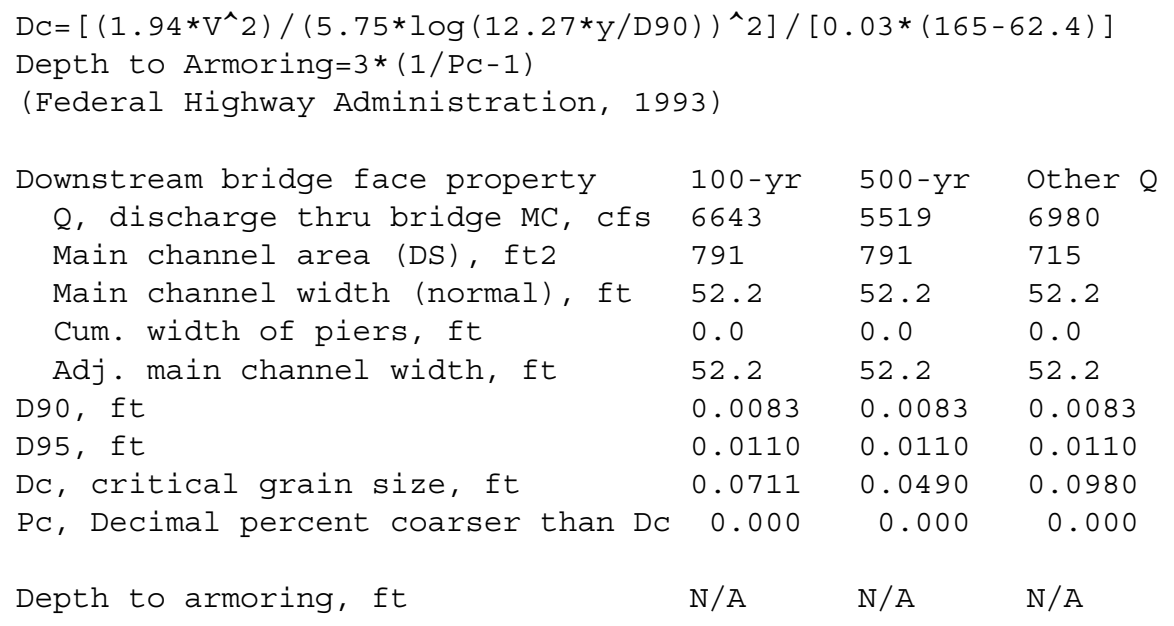

Abutment Scour

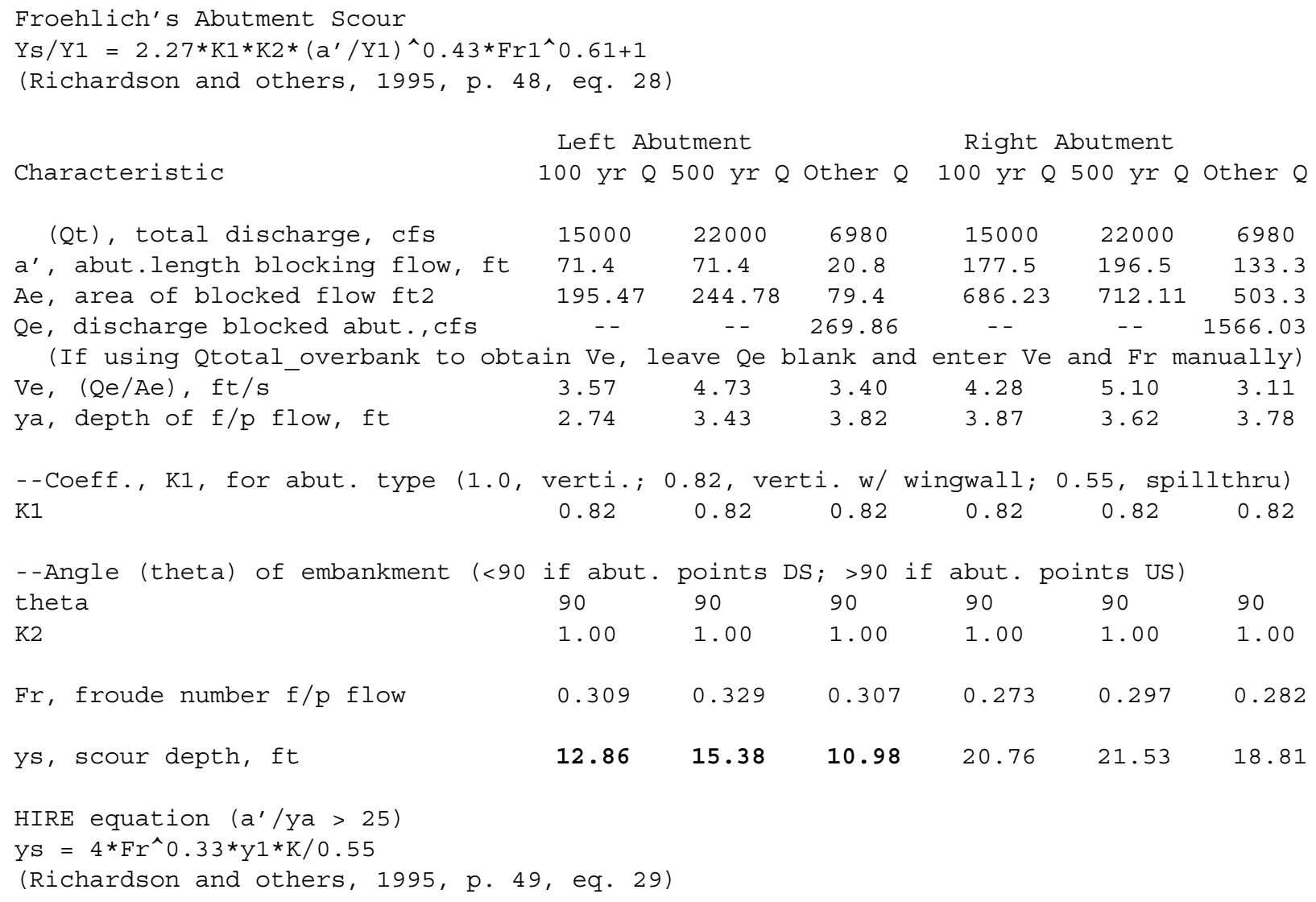




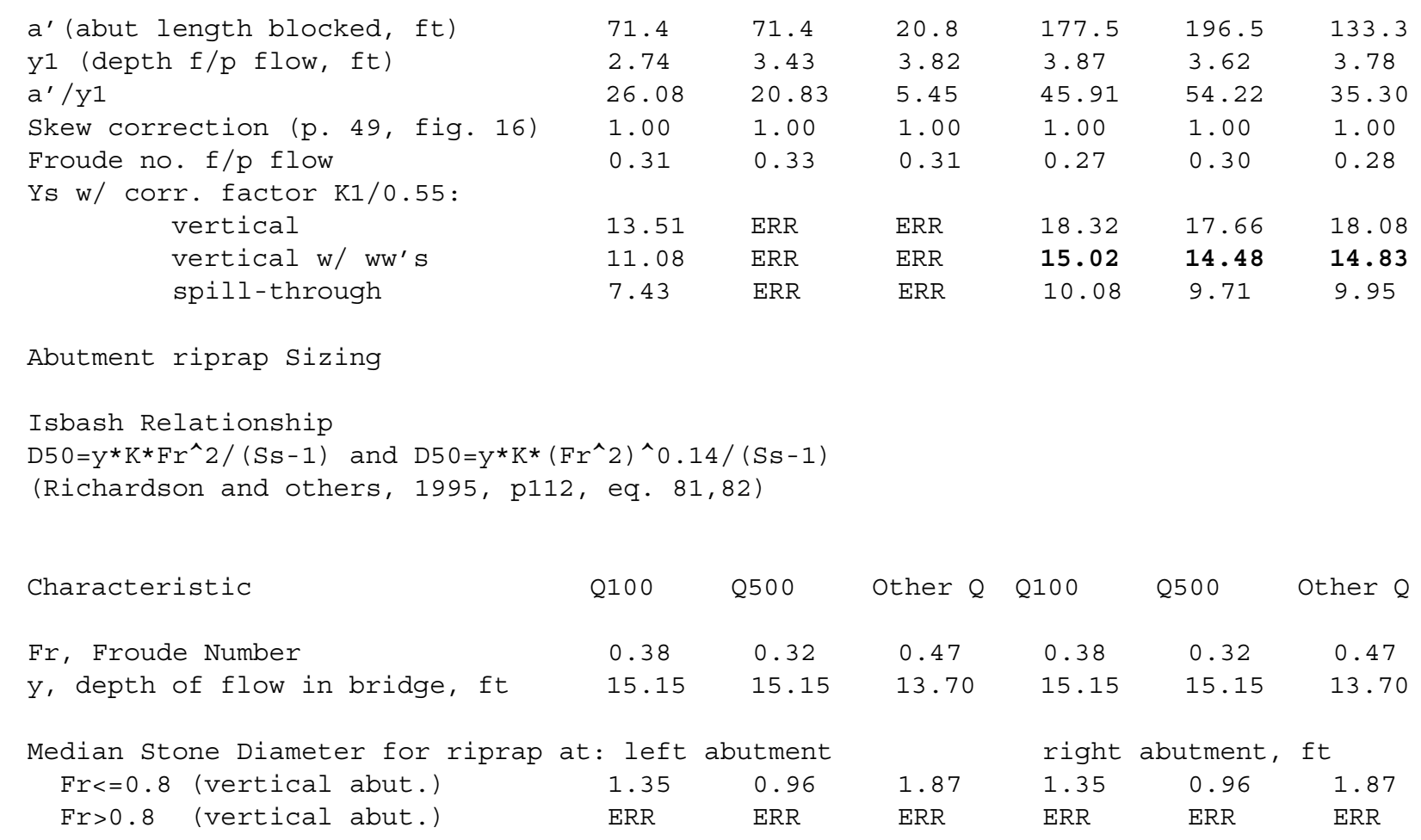

